\title{
Mirror, Mediator, and Prophet: The Music Indaba of Late-Apartheid South Africa
}

$\mathrm{T}$ his article explores a movement of creative initiative, from 1960 to 1990, that greatly influenced the course of history in South Africa. ${ }^{1}$ It is a movement which holds a deep affiliation for me, not merely through an extended submersion and profound interest in it, but also because of the co-incidence of its timing with my life in South Africa. On the fateful day of the bloody Sharpeville march on 21 March 1960, I was celebrating my first birthday in a peaceful coastal town in the Cape Province. Three decades later, on the weekend of Nelson Mandela's release from prison in February 1990, I was preparing to leave for the United States to further my studies in the social theories that lay at the base of the remarkable musical movement that had long engaged me. This musical phenomenon therefore spans exactly the three decades of my early life in South Africa. I feel privileged to have experienced its development-not only through growing up in the center of this musical moment, but particularly through a deepening interest, and consequently, an active participation in its peak during the mid-1980s. I call this movement the Music Indaba, for it involved all sectors of the complex South African society, and provided a leading site within which the dilemmas of the late-apartheid era could be explored and resolved, particularly issues concerning identity, communication and social change.

Indaba is a Zulu word meaning both an update on topical matters and a conference, symposium or meeting-place at which members of a group contribute equally towards the solution of a problem. It suggests combined efforts at working towards consensus through discussion of matters concerning the group as a whole. The word, of Nguni origin (including Zulu, Xhosa, and Swazi) has become integrated into the languages of most South

(C) 1998 by the Board of Trustees of the University of Illinois 
Africans, including English and Afrikaans language speakers. My experience of the music indaba resulted from being privy to an uncommonly diverse variation of social and musical arenas in South Africa. Growing up in a bilingual household (with English and Afrikaans family and friends), attending bilingual schools (the nature of my father's work meant three years was the longest I ever spent in one school), teaching in bilingual, multi-lingual, segregated, and multi-racial schools, and eventually lecturing in cross-cultural communications throughout the country to multi-cultural audiences in the business sector, I had the unusual privilege of experiencing "membership" of numerous diverse communities.

The democratic elections of April 1994, which issued in a new era in South Africa's history, signaled the culmination of a lengthy and painful process of resistances, conflicts, resolutions, and victories over not merely decades, but centuries. The complexity of the struggle has proven to be difficult, if not impossible, to illuminate through the confines of traditional methods of observation; whether through objective academic scrutiny, or through the more subjective discourses of party politics and media analysis. The unexpectedly peaceful and even euphoric time of the elections, which culminated in the final transition from apartheid to democracy (or "majority rule," the term some South Africans prefer at present) have presented analysts with an even more illusive mystery when referring to traditional models of conflict-resolution. In retrospect, the eventual transition towards democracy was not brought into being by a few key players at the official negotiation tables, but rather by average South Africans who had been unofficially negotiating for decades, if not generations. ${ }^{2}$

\section{Recent Models of Colonization and Resistance}

Traditionally, academic discourses about South Africa and indigenous discourses in South Africa have posited a simplistic dichotomy of two opposing factions, the African and the European, vying for power. While this binary trend is basic to the ideology of apartheid, it has long managed to conceal the complexity of the society living under the mantle of apartheid. This trend parallels a tendency to use "Afrocentrism" and "Eurocentrism" (even today) as yardsticks by which decisions are made-politically, socially and even artistically. While presenting useful (if not, at times, even expedient) poles within which people conduct their discourse, the tendency to conceptualize and speak within the constraints of this antithetical terminology has resulted in numerous oversimplifications and inevitable stalemates. The terms have become emblematic of the facile view of two opposing cultural factions: the African and the Western, or the Black and the White. ${ }^{3}$ This notion has especially been projected in representations of 
South African history, which has largely substantiated the polarizing image of opposing factions in a seesaw power struggle.

Fortunately, the accent nowadays has been shifting more from the doings of the powerful and the undoing of the powerless to the means by which bi-directional agency is expressed and achieved. The Comaroffs, for example, presented a model of "colonization of consciousness" through the religious mission (1991), while Franz Fanon long ago suggested a model of the de-colonization of that new consciousness through the revolutionary arts (1961). In Of Revelation and Revolution the Comaroffs deal with the role of the mission in colonizing consciousness, and how the process affects the sign systems (and consequently, the identities) of the colonized. After all, "the final objective of generations of colonizers has been to colonize their consciousness with the axioms and aesthetics of an alien culture" (1991:4).

The reverse process (which is central to this article), is dealt with by Fanon in his book The Wretched of the Earth (1961). Fanon presents the use of the creative arts in processes of resistance or revolution. He recognizes the need for an investigation and acknowledgment of this phenomena in order for any revolution to be successful. He sees the crucial phase of imitating the art of the colonizers as not only symbolic of final submission to a dominant power, but more importantly as the pivotal step toward resistance.

The process, from the initial arrival of colonizers, is contiguous. Initially there is the imposition of new art forms on traditional art-what Fanon terms processes of "cultural estrangement." (Fanon's use of the words "culture" and "cultural" refer to the products of creative initiative-literature, poetry, the plastic arts, and music - as opposed to the anthropological scrutiny of the defining qualities of a particular group.) The consequent imitation of imposed art forms by the colonized signals the demise of traditional ones, and with the artistic erosion comes the realization of a cultural loss. Although the disappearance of the traditional is never total, ${ }^{4}$ the demise of competence in traditional art forms is a critical symbol of a cultural void, and has larger connotations of ultimate submission. This moment brings on a realization of the meaningful loss, when the artist is "terrified by the void" (ibid.:220) and a consequent attempt is made at the revival of traditional art. Prior to being finally and irredeemably overwhelmed by the imposed culture, where "suddenly the language of the ruling power is felt to burn your lips" (ibid.:221), the colonized group, "hotheaded and with anger in their hearts, relentlessly determine to renew contact once more with the oldest and most pre-colonial springs of life of their people" (ibid.:210). Revived art forms are then instrumental in bringing on the final demise of the imitated ones, an important strategy of both resistance and revolution. 
According to Fanon, members of the colonized community go through three main phases over the period of the developments laid out above. In the first phase, where new art forms are being imposed, the works of the artists "correspond point by point with those of his opposite numbers in the mother country." In the second phase "we find the native is disturbed; he decides to remember what he is," and finally, in the third phase there is the movement to "shake the people" and "he turns himself into an awakener of the people" through creative works (ibid.:222-223). By creating works that will communicate messages of resistance, revolution and renewed identity, the artist needs "to go native as much as you can, to become unrecognizable, and to cut off those wings that before you had allowed to grow" (ibid.:221) (see Figure 1).

The models of the Comaroffs (in the colonization of consciousness and construction of identity) and Fanon (in the decolonization of consciousness and the revival of identity) are both valid and useful, particularly for their illumination of the numerous means by which power appropriations are manifested, and the contiguous nature of these processes. However, while dealing with opposing processes of colonization and resistance, neither model makes provision for the unique historical development that sets the complexity of the South African decolonization process apart from that of other post-colonial countries. While colonial withdrawal took place to a large extent with independence in other African countries, the colonizers did not withdraw with the advent of the 1961 "independence" in South Africa, but had by then substituted one form of external rule (colonialism) with a far stronger internal one (apartheid). While the Christian mission may have been partly responsible for a measure of the "colonization of consciousness" of the indigenous populations, it was not the only force at play, nor was consciousness colonized as completely or as unidirectionally as the model suggests.

\section{Figure 1. Fanon's Model of the Revolutionary Arts}

\section{The Process}

Imposition of oppositional art

Imitation of oppositional art

Demise of traditional art

Disappearance of traditional art

-Artistic void-

Revival of traditional art

Suppression of oppositional art

Demise of oppositional art

Reinstatement of traditional art

\section{The Symbol}

Colonization of identity

Erosion of identity

Loss of identity

Submission of power

- "The native is disturbed" -

Art as cultural weapon

Resistance

Revolution

Revival of identity 
Moreover, with the eventual "decolonization of consciousness" that took place with the democratization process (and consequently signaled the eventual end of official European dominance on the African continent with the historic elections held on 27 April 1994), South Africa was confronted with a unique cultural dilemma. No previous models have made provision for a reverse process so complex. It was not a mere unwinding of two strands - the colonizer and the colonized-or the reinstatement of one power structure over another. Rather, it presented a situation so complex with multiple discourses, encompassing both resistance and assimilation to such a penetrating extent, that an investigation towards a more complex model is needed to illuminate it. Furthermore, besides the fact that the transition was the result of a negotiated process rather than a revolutionary overthrow, and that it happened twenty to twenty-five years later than in most of the other African countries, it also had a more intricate and sophisticated network of communication and negotiation at its disposal, not least of which were a powerful and relentless struggle between opposing factions of the press, and of the recording industry. ${ }^{5}$ The power and relentlessness were facets of a bi-directional tug-of-war between the "official" and the "unofficial" - by suppression and censorship on the one hand, and resistance and protest on the other.

Dick Hebdige's presentation of the role of "subcultures," and the meaning of "style" (1979) is most useful for my purposes, not only in relation to power struggles between those in positions of authority and those disenfranchised, but especially in illuminating the complexity of South Africa's process of decolonizing the consciousness. Hebdige's notion of subcultures (or countercultures) makes provision for the multiple voices at play in the South African situation. It also offers explanations as to why subcultures (music movements, or other forms of protest art) are simultaneously disregarded as innocuous, feared as sinister, and ridiculed as meaningless. Ironically, extreme power lies in the subculture that is either being ignored or ridiculed on the one hand, or feared and censored on the other. The irony lies in that the power did not have to be fought for; it was earned through the very disquieting nature of the vehicle. Blatancy and subtlety, being the two opposite sides of the same game-card, are played to very different consequences. The flagrancy of censorship can usually be monitored and outwitted by the cunning of artistic initiatives, far more than the other way around. This inadvertent relinquishing and appropriation of power furthermore substantiates the notion that conspicuous and understandable protest is far less unsettling to the censor than protest that it cannot quite analyze the dis-ease of. A great deal of cultural capital is gained through unsettling style, or the establishment and re-appropriation of subtle new and old meanings-what Hebdige terms "resignification." 


\section{Previous Models of Historical Dualisms}

As was the case with the oversimplified black/white divide in South Africa, earlier anthropological theories of "polar dialectics" permeated ethnographies through the suggestion of simple versus complex, "bounded" versus "unbounded," cold versus hot, (Lévi-Strauss 1962), gemeinschaft versus gesellschaft (Tonnies 1957) and mechanic versus organic (Durkheim 1984). These have gradually moved towards a less alienating presentation of cultures as dynamic and accessible variations on a human theme rather than an "us and them" theme. It is no longer acceptable to present a synchronic image of a cultural moment in time as sufficiently representative of an individual culture. Cultures are less and less seen as static opposites on an evolutionary line, and more and more as ever-changing mutations on a multi-dimensional plain. The importance of history and change dictates a more diachronic approach towards thick descriptions of societies within cultural fields. The strict demarcations of cultural attributes that resulted from the polarizing us/them divide have also been reviewed, and a greater interest taken in what Gloria Anzaldua terms cultural "borderlands" which connect individuals and groups through more shared attributes and meaning systems (1987).

This shift has also had consequences regarding the question of agency. Simple presentations of unidirectional power impositions on powerless communities have been challenged by suggestions of bidirectional powerplays, where victories over the culture and consciousness of others is never complete, constantly in the balance, and always subject to the law of the pendulum's swing. Cultural norms are not simply shuffled and reproduced. They are rather more the results of negotiation, innovation, initiative, resistance, or appropriation. The more complex notions of cultural flux, borrowings, permeability and change have been explored by Katherine Ewing (1990) and Dorinne Kondo (1990) from the perspective of the multifaceted individual within a culture, not only within what were considered more "bounded" (rural) cultures, but also to the more "complex" (urban) cultures, and particularly across the spectrum of these two notions.

Cultures previously considered "simple" were seen as adapting over time to internal memberships and external circumstances. To many, such cultures experienced changes; they did not possess histories. They are now, however, increasingly being accepted as inherently and internally complex, having their intricate cultural systems continually exposed to both native and foreign influences. Impositions of alternative systems are constantly being contested by the active appropriation of, and even influence on, those alternatives. Instead of being subject to a process of unidirectional agency, those viewed as powerless are often recognized as being considerably pro- 
active in a process of bidirectional agency. ${ }^{6}$ The tendency in anthropology today, then, is moving towards recognizing the complexity (in both time and space) of individual and socio-cultural phenomena. ${ }^{7}$ It is also moving towards revealing the complexity of the agents of change, and the importance of these agents in resolutions to local or global conflicts.

Ethnomusicologists have long been focusing on the role of the arts in revealing or affecting larger social and political realities; how the arts reflect the zeitgeist of the time. Initially most of the work was done, much like the early leanings in anthropology, with a focus on "contained" cultures. Attempts were made to reveal cultural components in a frozen moment through analysis and illustrations of ritual, art, music, or dance. Later, attention was given to the development of these genres across time, or the introduction of influences across time, with the more ambitious aim of revealing something larger about the social or political development of either one group across time, or of the diglossia resulting from contact between two groups. The early tendency was once again to see Western (complex) musical traditions as revealing historical developments, and non-Western (simple) musical traditions as experiencing changes. More recently, however, the trend is leaning towards the anthropological theorists' tendency simultaneously to recognize developments and influences both across time and between numerous cultures. Furthermore, the mission of music as cultural agent of both stability and change in a fast-changing world has presented the field with complex challenges. The elaborate interplay of voices between numerous groups-heteroglossia, as Mikhail Bakhtin would term it (1935)-merges into sometimes harmonious, sometimes discordant soundscapes. The roles of the influencer and the influenced are constantly challenged and switched. This bidirectional approach simultaneously reveals further complexity and depth in exposing underlying socio-cultural realities.

\section{Background of the Music Indaba}

Hebdige's discussion of the role of "subcultures" is useful in an exploration of the South African discourses which contributed towards a bidirectional democratization process. Great divides have long existed between what have been presented as "official" culture and "unofficial" subcultures (or countercultures) in South Africa. The constant interplay between the official (seen as "normal") and the unofficial (often considered "abnormal") creates the endless process that Karl Marx and his forerunner G. W. F. Hegel called the friction between "thesis" and "antithesis," moving stringently and inevitably towards a new "synthesis." This in turn becomes the new thesis against which a new antithesis will develop, either gradually through resolution or suddenly through revolution. Eric Wolf also spoke of this process 
in relation to social movements as constant "conflict and accommodation; integration and disintegration" (1982). The vehicle of protest music as a social movement in South Africa reveals a more complex process than a mere clash between two binary oppositions (as would have been the suggestion in earlier dialectics), but rather as sounding variations on cultural themes.

The unofficial countercultures, particularly the subculture of music, served three main purposes: symbolic, practical, and tactical. Symbolically, it facilitated personal revelation; practically, it assisted social re-cognition; and tactically, it asserted political resistance. The symbolic objective served the purpose of reasserting identities after decades of a distortion (or even invention) of identities; whether as a result of fabricated roles or suppressed ones. Music could serve as a vehicle to reappropriate what had been usurped, or to reevaluate what had been invented. It could, in short, be used to retrieve identity, to express identity, or to preserve identity. The practical objective served the purpose of communicating across and within cultural borderlines after decades of enforced segregation. This was achieved either through communicating with others inside the group, with those outside the group, or reviewing the borders of who was inside and who was outside the group. The tactical objective served the purpose of mobilizing social change, whether with the more concrete intentions of invoking peace or threatening war, or with the more abstract intentions of recovering or reflecting a past, suggesting or establishing a present, and projecting or prophesying a future.

South African music, especially in this century, reflects these three objectives to a great extent, and is both mimetic and prophetic of the sociopolitical realities in the country. Scholars like Hugh Tracy, Percival Kirby, John Blacking, and David Rycroft delved into the components of "traditional forms," laying solid foundations on which future ethnomusicologists could develop their inquiries. Much outstanding work in ethnomusicology has since traced the development of genres as they moved through the trials of the decades leading to the democratization process.

While some works still focus on the intricacies of particular forms and instrumentations (Clegg 1981; Clegg 1982; Davies 1994) others discuss music as a reflection of social history (Ballantine 1989; James 1991) or the larger politics and aesthetics of music and the entertainment industry (Anderson 1981; Coplan 1978; Coplan 1985; Erlmann 1991). Music is dealt with both as a reflection of the urbanization process (Coplan 1982a; Coplan 1982b) and as a vehicle and expression of emancipation (Ballantine 1991a; Ballantine 1991b; Kivnick 1990; Tomaselli and Boster 1993). Interesting work has also dealt with the praise poem (White 1982; Vail and White 1991), the kwela pennywhistle style (Allen 1993), women's music (Rorich 1989; James 1994; Muller 1994) and women's toyi-toyi slogan-chanting (van 
Schalkwyk 1994). Two themes recur throughout many of the most prominent works on South African music. The first is the issue of migrancy (dealing with continuity and change), particularly of the Zulu and the Basotho (Erlmann 1990; Coplan 1988; Coplan 1994; Wells 1994). The second is the fusion of styles (through syncretic genres) like in the early marabi culture (Coplan 1979-1980; Ballantine 1993). Besides exchanges between local communities, attention has also been given to receptions and disseminations between South Africa and popular American music like Rock 'n Roll (Hamm 1985) and African-American styles (Hamm 1988). The significance of Paul Simon's Graceland album, especially as representative of the use of black forms like Zulu isicathamiya in fusions with "commercialized" western (or imported trends), has been a source of much debate both outside the academy and within it (Hamm 1989; Meintjes 1990; Feld 1994).

This sample of seminal works shows that the focus of inquiry has to date revolved primarily around black music in South Africa. More recently, however, there has been a recognition of the importance of the musical forms of communities other than the disenfranchised in the resistance movement. Numerous insightful studies have dealt with certain resistance styles and collaborative ventures of the time, of which the Afrikaans Alternatiewe movement of the late-eighties (Smit 1992) is a particularly interesting phenomenon. Even in the arena of classical music, academics and musicians have written about the significance of the crossover works which are creating a uniquely South African genre of "ethnoclassical" music (Levy 1986; Levy 1992; Roosenschoon 1992).

The above overview further reveals that while many autonomous genres have enjoyed separate scrutinies, there has been a growing recognition of the importance of the syncretic styles (like the marabi style) that developed initially out of circumstance, from the urbanization process. No single inquiry, however, has concentrated on the gradual and complex integration of diverse styles (like afropop and ethnoclassical fusions) that developed later, out of necessity, to so intricately reflect the complex socio-political realities of the democratization process. This interplay of syncretic styles, as a comprehensive movement, is a phenomenon that cannot be ignored, for it played a prominent and powerful role in the larger social and political developments in the country throughout the democratization process. Its beginnings were found in the earliest attempts at resistance or protest music and reached a peak in the mid-eighties with the apex of the truly "syncretic" styles. ${ }^{8}$

\section{Waves of Resistance and Protest}

The history of musical traditions in South Africa, much like the trends of social consciousness reflected in them, are punctuated by seminal his- 
torical events, and can be seen in two contiguous waves of insurgency. The first wave, from 1912 to 1960 , was characterized by resistance, while the second wave, from 1960 to 1990, was characterized by protest. Resistance consisted of expressions of refusal to accept or conform to a situation, while protest consisted of expressions of determination to be pro-active mobilizers of social change. ${ }^{9}$ Besides the effect that influential historical moments had on the musical movements, four remarkable characteristics serve as a demarcation between these waves.

First, there are the players who were in the movements. While the first wave (of resistance) consisted primarily of musicians from the disenfranchised communities, the second wave (of protest) was all-inclusive, benefiting from the involvement of members of every community. ${ }^{10}$ While the first expressed the dilemma of those groups and individuals at the mercy of the apartheid ideology, the second included the protests of privileged communities concerned with the moral issues underlying apartheid policies.

Secondly, the earlier wave of creative endeavors against the policies of segregation were far more in the form of an exclusive homogenous dialogue (between the disenfranchised) against an outside force. David Coplan describes how "urban musicians built cultural bridges between members of the African community" (1978:139) while Thomas Cushman substantiates how in South Africa "music was instrumental in helping blacks to share their common experience of subordination and to carve out an autonomous cultural space in which they could redress their grievances" (1995:9). The later wave, however, consisted of a more inclusive heterogeneous dialogue (between both the voting and the voteless public), and gathered momentum in search of collaborative consensus. It is this issue of collaboration that sets the music indaba apart from previous resistance movements, and that, in essence, contributes to its remarkable power and effectiveness.

Thirdly, there was a marked difference between the waves in terms of the approach and tone of the music. In the earlier movement, expressions of resistance were increasingly blatant, while simultaneously managing to maintain a tone of (often naive) optimism in the face of immense hardship. In the second movement, expressions of protest in the wake of stringent censorship were created with increasing subtlety, while simultaneously developing a tone of disillusionment, anger and resolve. One observer suggested a pair of interesting images to compare the two movements (Boyce Byerly, pers.com. 1994). The first image described the differentiation in terms of a comparison between steam and pressure. The earlier movement resembled an environment where steam could gradually escape, and was therefore cathartic to a certain extent, but not fully effective in the long run. It could be clearly observed and therefore easily suppressed. The later movement, however, resembled an environment so repressed from the start 
that the pressure steeply built up in the stifling environment, eventually resulting in the creation of ingenious methods to effectively release itself. It could not be clearly detected, and therefore not easily checked. The second image compared the earlier movement to the slow appearance of weeds across a field, and the later movement to the reaction of the weeds when paving is laid over it to stifle its growth. It eventually breaks through the restrictive barrier at the most unexpected times, in the most unexpected places, and in the most unexpected ways. The applicability of this image is interesting in that, while the early development and growth is blatant, the second is more subtle. This greatly reflects the more spontaneous nature of the early resistance genres, and following the clampdown on artistic expression, a change of tactics was required. This resulted in the more cunning, yet more conscious and concerted approach of the protest genres of the second wave. The trends moved from the explicit, overt emoting of early resistance to the implicit, covert strategies of later protest.

Finally, there is a marked difference between the reasons why each wave ended. The first, more gradual rise (of resistance) was destroyed at its crest by a strong repression of the swell by official forces. The second, more concerted surge (of protest) rode out its crest, resolved itself and dissipated. It voluntarily handed over its mission in 1990 to the political forces that had been liberated for the purpose of a negotiated transition. Christopher Ballantine believes that "the tremendous excitement of the music of the late ' 80 s stopped. It was no longer possible for the scene to be that dynamic. Because things were happening politically there wasn't the same pressure for it to occur" (pers.com. 1995). Yet at its peak in the late 1980s, during what Ballantine calls "the musical euphoria of the years between the mid-1980s and the start of the '90s" (1993:9), participants fully experienced the power of the musical momentum and basked in the fervor which the musicians provided (and their audiences received) through the musical messages. There existed an intense, soaring wave of conviction that things were being achieved through an unsurpassed effort of collaborative artistry in the country. A description which most effectively captures the nature and intensity of the movement is found in Hunter Thompson's description of the rebellious "wave" of the American '60s:

History is hard to know . . . but even without being sure of "history" it seems entirely reasonable to think that every now and then the energy of a whole generation comes to a head in a long fine flash, for reasons that nobody really understands at the time-and which never explain, in retrospect, what actually happened ... You could strike sparks anywhere. There was a fantastic sense that whatever we were doing was right, that we were winning . . . And that, I think, was the handle-that sense of inevitable victory over the forces of Old and Evil. Not in any mean or military sense; we didn't need that. Our 
energy would simply prevail. There was no point in fighting-on our side or theirs. We had all the momentum; we were riding the crest of a high and beautiful wave. (1971:67-68)

Figure 2 suggests the movement of the waves of "unofficial" South African musical countercultures, the first propagating open resistance and the second developing more veiled forms of protest. It also backgrounds the movement of the "official" cultural trends, revealing the impositions of "acceptable" art forms to be inversely proportional to the reactionary resistance movements. ${ }^{11}$

Historically, the first wave reflected the social divisions of the early days of segregation, particularly with the effects of the Native Land Act of 1912. The date of this Act is significant, and therefore used to demarcate the start of the first wave, as its consequences for the black population in South Africa were devastating and far-reaching (see Keegan 1988). The year marked not only this new appropriation and allocation of land by the government (and the consequent forced removals and migrations of countless black families who had previously owned land), but also the formation of the South African National Native Congress in the same year. These two seminal developments marked new resolve on the part of both the government and

Figure 2. Movements of Resistance (1912-1960) and Protest (1960-1990)

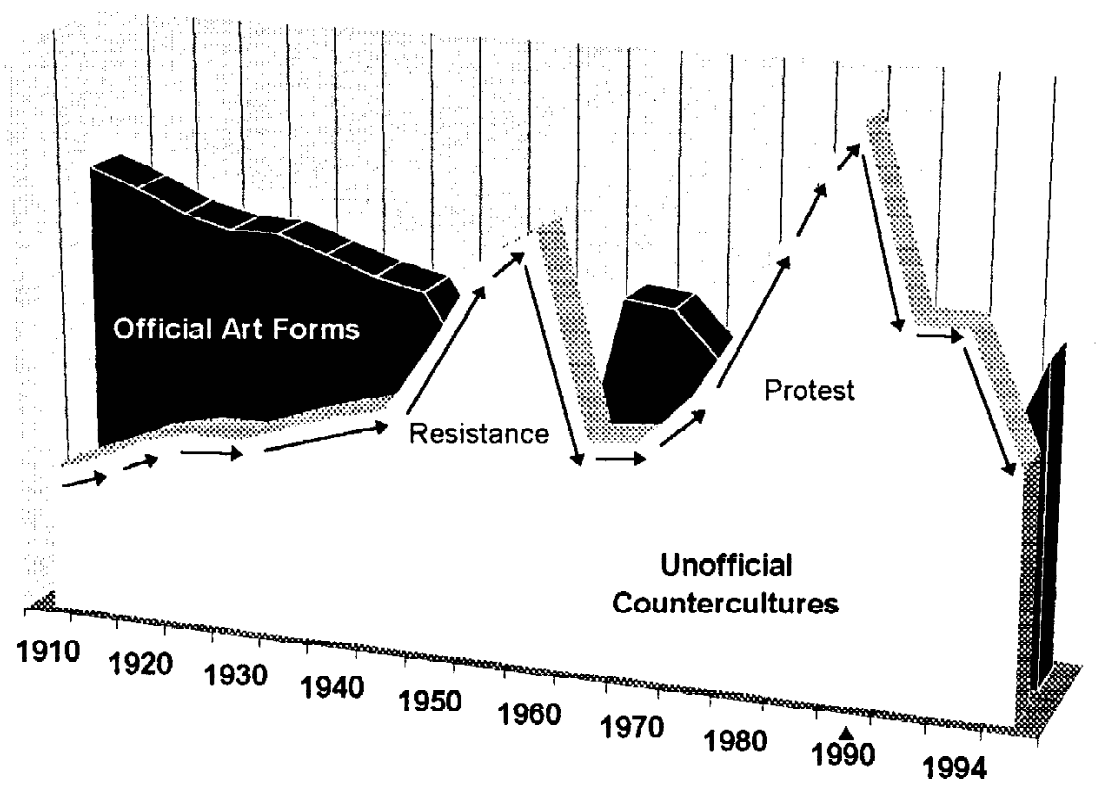


the black population to mobilize and maintain movements of power and resistance. The wave peaked in the establishment of official policies of apartheid in 1948. This resulted in legal acts such as the Group Areas and the Immorality Acts of 1950, and had consequences in determined anti-apartheid strategies, from the "passive resistance" campaign of the African National Congress (ANC) in 1952 until the violent Sharpeville clashes of March 1960.

Musically, this wave is parallelled by the more traditional music styles like Zulu isicathamiya and maskanda forms, sefela of the Nguni and Sotho language groups, and mission-influenced makwaya choral music. It also reveals the early divisions of volksmusiek of the Dutch (later Afrikaans), and folk music of the English communities on farms and in towns, and the marabi tradition of the townships. These grew into the flourishing light music, boeremusiek and symphonic traditions of the white communities, and the ghommaliedjies, mbube, tsaba-tsaba, township swing, township jazz, kwela, and mbaqanga (or simanje-manje) styles of the communities registered as "non-white." The destruction of Sophiatown, one of the most fertile areas of creative musical initiative in the 1950s (inhabited, problematically for the government, by a growing multi-racial community), and the severe new broadcasting policies of the South African Broadcasting Corporation (SABC) in 1960 (see Hamm 1991), drove the most influential and revered musicians into exile abroad. (The most notable examples of these exiles were Dollar Brand [now Abdullah Ibrahim], Miriam Makeba, Hugh Masekela, and Chris McGregor.) These catastrophic events temporarily silenced the music in a similar way to the forceful suppression of the passive resistance campaigns and the consequences of Sharpeville.

The second wave of creative initiative ran from the time of the 1960 Sharpeville event through the upheavals of the Soweto Riots of June 1976, the resulting "renewed master plan" of the SABC, the national unrest spurned by the Uitenhage riots of March 1985, and the declaration of the consequent State of Emergency. It ended with the election of F. W. de Klerk as President in 1989, his December announcement that previously outlawed political groups, like the Pan African Congress and the ANC would no longer be banned, and the historic release of Nelson Mandela in February 1990. These are the 10,900 days of complex human drama that went from despair to euphoria; from the funeral dirges of the Sharpeville victims in 1960 to the triumphant anthems of Mandela's inauguration in 1994.

Musically, the 1960s reflected the debilitating effects of the new broadcasting policies. They were also marked, however, by the persistent efforts of artists who refused to bow out of the struggle. Numerous English-speaking folk singers and satirists performed in coffee bars like the "Troubadour," risking more than their careers in the pursuit of free artistic expression. ${ }^{12}$ 
Meanwhile, similar sentiments were being expressed through bitter protest songs on the other side of town at the mining hostels and shebeens (illegal drinking houses that became popular in the townships as a result of the prohibition laws that existed for blacks at the time) of the townships.

The early 1970s saw mounting censorship, and while Afrikaans musicians sang lekkerliedjies ("nice song," a bland form of easy-listening with lyrics centered around flora, fauna and geographical locations to avoid controversial issues), English-language pop songs were conspicuously frivolous, or imported. Protest musicians of all ethnic backgrounds were heavily censored if their lyrics were too controversial or politically charged, and many were forced to change their focus to compositions in the lekkerliedjie vein, or laud the benefits of "separate development" and cultural diversity through (often-invented) autonomous identities. The results of this dilemma, however, turned out to be both fruitful and important, as it caused those who were not in exile already, and unwilling to succumb to the pressures of imposed censorship, to go underground and perform their protests in clubs, shebeens and other township venues. Even churches became sites of resistance. By the late seventies, the mood had become more resolute on the part of both the censors and artists, causing an interesting result. Closer scrutiny by officials forced musicians to discover ways in which they could, through ingenious compositional and textual strategies, outwit the censors. The subtle use of musical components imaginatively expressed resignification, resistance, and revolution. Humor, cynicism, criticism and irony could all be expressed through the careful revival, reconstruction, manipulation, and superimposition of varied themes, rhythms, and harmonies. The deployment of creative instrumentations and the resourceful use of code-switching between the country's numerous languages further added to a lively musical and lyrical discourse that managed to outwit even the most stringent scrutiny. Traditional music styles were revived to suggest tongue-in-cheek nationalism, folk themes were aggrandized to imply one thing while meaning another to the astute audience, and the ironic use of melodies could mislead the analyst expecting obvious meanings where suggestions were more obtuse. The innovation of new themes and styles created whole new genres of non-traditional sounds. Most importantly, the growing trend of syncretic and collaborative styles utilized the juxtapositioning of traditional and nontraditional themes, styles, instrumentations and rhythms, causing superimpositions that were symbolically harmonic as well as symbolically discordant.

In the early 1980s, while disposable English pop bands, Afrikaans lekkerliedjie artists, and various msakazo musicians ("radio music" musicians, the insulting term given to mbaqanga artists who bowed to official politi- 
cal agendas) still had brief, lackluster careers on charts in the country, ${ }^{13}$ strong sounds of resistance and protest genres were making inroads into the mainstream. This development could be largely attributed to a handful of Afrikaans musicians who had by then branched into two new avenues of expression, starting what was to become known as the "Afrikaans Renaissance." The musiek en liriek movement, targeted at the more conservative audiences, reviewed the importance of meaningful lyrics by substituting the inane lekkerliedjie with the more thoughtful luisterliedjie ("listen song," a meaningful ballad where the essence of the song was in the poetry of the lyrics, requiring careful listening, and loaded meanings replaced bland "nice" lyrics). Simultaneously, the East Rand Rock movement, conceived by younger musicians and targeted at the new breed of more progressive Afrikaans audiences, played aggressive, angry rock challenging both external forms of authority and internal notions of personal identity. ${ }^{14}$ Both these forms challenged past images of "the Afrikaner" and attempted to reevaluate past ideologies. The objectives for this often uncomfortable strategy of soul-searching were both to critique the stereotypes and to expose the aspects of the stereotype that were possibly valid. The grand design, of course, was to facilitate change in not only the image of Afrikaners, but their relationships, the directions in which they were moving, and their very identity.

By the mid-1980s, the two Afrikaans forms of the luisterliedjie and East Rand Rock had developed into more direct challenges to audiences: one in the form of intimate, often unsettling Kabaret performances, and the other in the form of the more controversial movement of alternatiewe musiek, led by a group of eccentric musicians who had taken on absurd pseudonyms as commentary on the absurdity of the social agendas around them. More generally popular, however, were the collaborative or syncretic music styles that had, after twenty years of experimentation, developed from marginalized forms to mainstream genres in the country. Combinations as unlikely as traditional musicians and symphony orchestras combined to produce "ethnoclassical" works, rock groups and jazz bands combined with traditional instrumentalists to create the "afro-rock" and "afro-jazz" styles, and mbaqanga musicians teamed up with boeremusiek artists to create a whole new genre which became known as boereqanga. The inclusive nature of these musical offerings assured their appeal with many sectors of the public, and were, as a result, particularly influential in their social achievements. It is with these developments that the three agendas of music in South Africa's transition time began to assert themselves most forcefully: the symbolic (for renewal of identity), the tactical (for intercultural communication) and the practical (for political mobilization) (see Figure 3). 
Figure 3. Development of Musical Styles from Autonomy to Collaboration

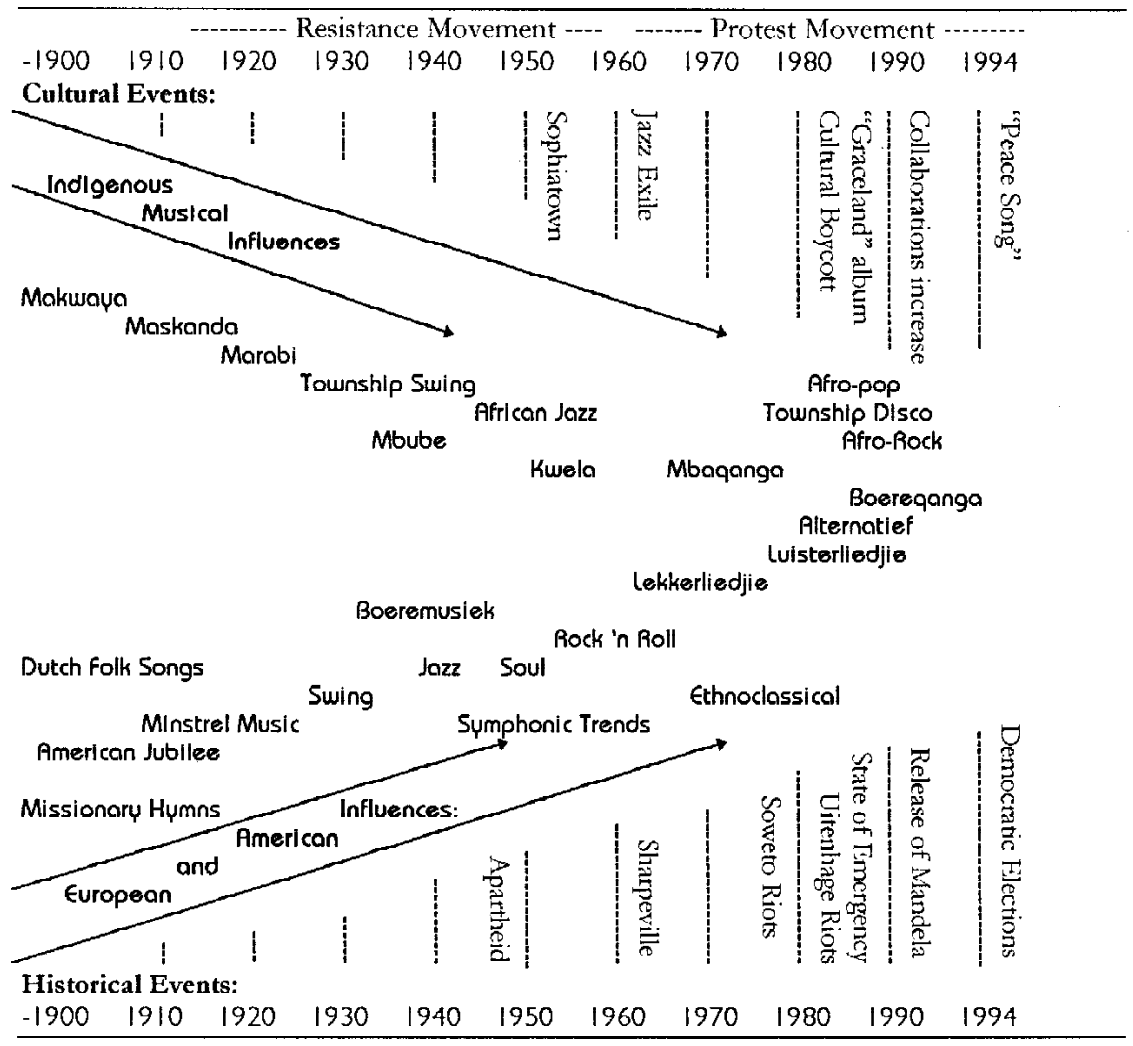

*Note: This figure serves as a visual representation of seminal genres as they moved from their approximate appearance towards trends of collaboration. Some styles are, of course, more influential than others, but suggesting these details would not only be subjective, but also add excessive complexity to the visual image.

\section{Music as Mirror: Towards Symbolic Revival of Identity}

There are so many unresolved things. For me it sorts out my own identity. It's a means through which I can find out where I come from and where I'm going. The history of 'Mosaic' is the history of our becoming South Africans. The music was so truthful that I could articulate and discover things I had not previously articulated or discovered. All kinds of social and emotional things happened for me. It articulates my multiple identity, and our collective one. (Nishlyn Ramana, pianist in the South African group Mosaic, pers.com. 1995)

Throughout the democratization process, painful personal dilemmas faced most South Africans in not only reviewing, but also rediscovering, 
redefining, or reconstructing their individual and collective identities. This was necessary not only considering the practical expectations of a post-apartheid South Africa, but especially from a symbolic perspective. The numerous styles of the era (both autonomous and collaborative) reflect not only the complexity of the social fabric, but also the dynamic nature of that complexity. Musical styles moved in dense counterpoint which constantly reassessed the interplay between people, mediating the inclusion and exclusion of voices to suggest redefinitions of both individual identity and group membership. Sound structures and lyrical content continuously redrew the boundaries of what Benedict Anderson would term "imagined communities" (1983). Music venues had been strictly segregated, either by law, or by the social conventions resulting from earlier imposed segregation. But by the mid-1980s multi-racial venues in the form of clubs like "Kippies" and "Jamesons," as well as large music festivals like the Grahamstown Festival, Splashy Fen, Houtstok (Woodstock), and numerous others served as open arenas within which social demarcations could be constantly challenged.

Issues of identity, particularly with regard to renewals of ethnicity and group affiliation, were explored primarily through the revival of traditional and older (or even forgotten) genres of various communities. There were two approaches towards these revivals; first there were the purists, who believed the traditional forms should be rescued and preserved in their "authentic" idiom, and second there were the progressives, who wanted these neglected styles to be integrated into "modern" musical idioms and reconfigured in a way that would be accessible to a wider audience. ${ }^{15}$ Within the narrow confines of the purists and the wider scope of the progressives, revivals could further be divided into four main categories; those recovered for (autonomous) cultural renaissance or the forging of a (collective) new nationalism, those refashioned for historical review, those reviewed for cultural critique and those reconstructed or translated for cultural elevation.

As Fanon suggested, it was the artists themselves who first detected the cultural "void" of these lost or neglected genres, and who sought to revive and reinstate the art of a group in order to re-assert the identity of the group (1961) ${ }^{16}$ Their art forms became, in the pursuit of renewed identity, a cultural weapon. As a result of efforts towards autonomous cultural renaissances there was the sudden appearance of numerous genre revivals, particularly towards the beginning of the 1980's. Boeremusiek, which had become an almost forgotten form (if not, according to some, an embarrassing form), suddenly experienced a surge of interest. There were televised competitions organized by the Boeremusiekgilde, and this in turn sparked renewed interest in the form, not only within the Afrikaans community, but also with those outside the community. Non-Afrikaners would attend boeremusiek events, or learn instruments specific to that style, and as a result the boeremusiek community itself expanded, and become more inclusive. 
Another genre which experienced revival was the Afrikaans folk song (volksliedjie), especially with the advent of the musiek en liriek movement of the late-seventies. Sung verses and poetry in the vernacular became the center of a new cultural renaissance for the Afrikaner, where previously English pop had been the fashionable cultural form. Of course the sudden popularity of Paul Simon and Ladysmith Black Mambazo's Graceland album ensured the revival and popularity of the isicathamiya singing style with members of all cultural groups. Interest in this form had previously been restricted to African communities, especially in the mining hostels, where competitions were held on weekends. While the judges chosen were usually white (for their impartiality as a result of their unfamiliarity with both the style and the competitors), it was only after Graceland that the style became part of the general South African soundscape.

Like Zulu isicathamiya, revivals of Sotho sefela also became more accessible to a wider audience, and musicians like Lesego Rampolokeng started experimenting with the possibilities of sung poetry in a modern idiom. His collaborations with the group The Kalahari Surfers fused the traditional with the contemporary, expressing political sentiments in poetic tones over synthesized musical accompaniment. The fusion made greatly varying audiences feel included in the cultural fabric of the music.

An interesting aspect of revivals was the double agenda that they managed to serve. While they could separate and define, they could also fuse and assimilate. Some autonomous genres were revived or adapted to express particular ethnic identities or renewed social affiliations, while collaborative styles also developed to express a renewed communal identity in the form of a new, inclusive South African nationalism. These forms fused previously autonomous genres and styles to incorporate all ethnic groups and linguistic and cultural affiliations. One of the most interesting cases, with the agenda of fusion rather than division, is the group Mosaic. Comprising students from diverse backgrounds at the University of Natal, they compose and improvise pieces incorporating Indian classical music with traditional African components, North American jazz, and classical art music.

Revivals of traditional genres further served as a form of historical review and a site for contemplation about the past. Connections were made, by Afrikaners particularly, with singers and music from Holland (the European vaderland of the Afrikaner), as well as singers from Belgium who spoke Flemish. The South African artist Johannes Kerkorrel, for example, not only teamed up with Stef Bos in Europe, but also brought Bos to South Africa to record with him. The artistic "reconnection" with a past of over 330 years ago is symbolically significant, especially in the wake of previous efforts made by Afrikaners over the decades to sever ties with their European ancestry and forge a complete connection with the African con- 
tinent. In an even more pertinent development, some artists composed works representing the present by connecting with both symbolically historical and projected future social unions. An example of this fusion to represent multiple identity is Kerkorrel's song "Awuwa," in which the Afrikaner teams up with his European past (Stef Bos) and his African future (Tandie Klaasen) to present an interesting blend of contrasting yet harmonious voices. Relationships between groups were also explored in certain works, like Anneli van Rooyen's Songs from the State of the Heart, a cabaret song series exploring the historically contentious and explosive relationship between the British and the Boers in South Africa.

In considerations of identity, music served prominently as a site of contemplation concerning the image of the Afrikaner-whether the old stereotype or the new incarnation of Afrikaner. This was done primarily through challenging historical images of Afrikaner identity, as is apparent in Kerkorrel's song "Ossewa." The oxwagon, symbol of the conservative, God-fearing pioneer trekking into the unknown, is in this song depicted as a fashionable vehicle that transports the Afrikaner, accompanied by rock ' $n$ roll music, to a holiday at the coast with beer instead of the family bible in the wagonchest.

\section{Ossewa}

Ek staan hier langs die highway met my ou vriend Mike

ons twee was op pad om Transkei toe te hike die son bak neer, dit was baie warm

weer,

ons was amper reg om moed op te gee

maar skielik in die verte blink 'n spikkel in die pad

dit kom vinnig nader, ja die ding het laat spat

ek kon my oë nie glo nie, my verstand kon dit nie vat

Genade Gert dis 'n nuwe soort ossewa osswewa, osswea, ja 'n ossewa

'n Klein entjie verder begin die ding kalmeer hy kom tot 'n stilstand met remme wat skree

'n ou oom klim uit, se ons moet nadertree

hy gee nie om om vir ons 'n lift te gee hy het sy ossewa woema gegee hy het 'n V-6 engine binne -in gemonteer en 'n tape-deck waarop Elvis kliphard skreeu

dit was 'n regte egte rock 'n roll ossewa ossewa, ossewa, ja 'n ossewa

\section{Oxwagon}

I'm standing at the highway with my old friend Mike

The two of us are hiking to the Transkei

The sun bakes down, it is very warm weather

we were nearly ready to give up hope

but suddenly in the distance shines a dot in the road

it approaches very fast, yes the thing can fly

my eyes could not believe it, my mind could not take it

Mercy me, it's a new type of oxwagon oxwagon, oxwagon, yes, an oxwagon.

A little way along the thing settles down

he comes to a halt with breaks which screech

an old uncle gets out, he says we must approach

he doesn't mind giving us a ride,

he revved his oxwagon

he had a V-6 engine mounted inside

and a tape deck on which Elvis Presley screams loudly

it was a real, true rock 'n roll oxwagon oxwagon, oxwagon, yes, an oxwagon. 
Ons cruise langs die highway af

duidelik nie van hier

teen 'n honderd en sestig kilometer 'n uur

die ander karre op die pad het ons gou

verbygegaan

hy bied vir ons bier uit sy wakis aan

'n groot span osse sleep hy agter ons aan

in 'n uniek ontwerpte dubbel-sleepwa

hy trap die lepel plat en ons is vinnig by die see

in ons funky nuwe rock 'n roll ossewa

ossewa, ossewa, ja 'n ossewa

sweet sweet ossewa ons ry in 'n ossewa.
We cruise down the highway

clearly not from around here

at one hundred and sixty kilometers an hour the other cars passed us

quickly

he offers us a beer out of the wagonchest

a great span of oxen he pulls behind us

in a new double-trailer

he puts his foot down flat and we're soon at the sea

in our funky new rock 'n roll oxwagon

oxwagon, oxwagon, yes an oxwagon

sweet sweet oxwagon, we ride an oxwagon.

For another example, in the song "Mystic Boer" Valiant Swart contests the stereotyped image of the Afrikaner as an ignorant farmer, presenting a sophisticated agriculturalist with a deep mysticism. The portrayal is strengthened by religious imagery (the Great Trek being described as forty days and forty nights in the desert) and there are dramatic modulations and original switches between genres (the cowboy "riding" theme, played on the mandolin, merges into sweeping orchestration at the suggestion of reaching the Promised Land of the Transvaal). The lyrics juxtapose respect and critique, and the song manages to present an image of a complex historical figure rather than a one-dimensional stereotype.

Revivals serving as cultural critique utilized old or well-known forms from within which to challenge the status quo and to expose any signs of truth in negative images of identity. Venues like Pretoria's "After Dark" and Johannesburg's "Black Sun" were fertile sites of musical commentaries, particularly in the form of disquieting cabarets. Artists like Nataniel and Elsabe Zietsman provided audiences with startling, unnerving, and comical performance art dealing with overtly controversial and previously taboo subjects like religious alternatives, political situations, inter-racial relationships, and homosexuality. The musicians of the Alternatiewe Beweging (Alternative Movement), such as Koos Kombuis (previously Andre le Toit), Randy Rambo (previously Teunis Engelbrecht), and Bernoldus Niemand (previously James Phillips) were particularly critical members of the artistic community, especially with regard to their own history and identity: members of this movement adopted absurd pseudonyms to reflect "the absurdity of the society we belonged to, and to ridicule the cultural identity we were part of" (Johannes Kerkorrel, pers. com. 1996). Casper de Vries jibed at his Afrikaner identity through the adaptation of beloved nursery rhymes with disturbing "alternative" lyrics. A childlike tune was sung "innocently" with simple instrumental accompaniment (Example 1). The lyrics were shocking and revealing, deliberately exposing the sordid underbelly of South African society. This forced audiences to review their apathetic tolerance of previously ignored realities: 
Example 1. "Feetjieland" melody

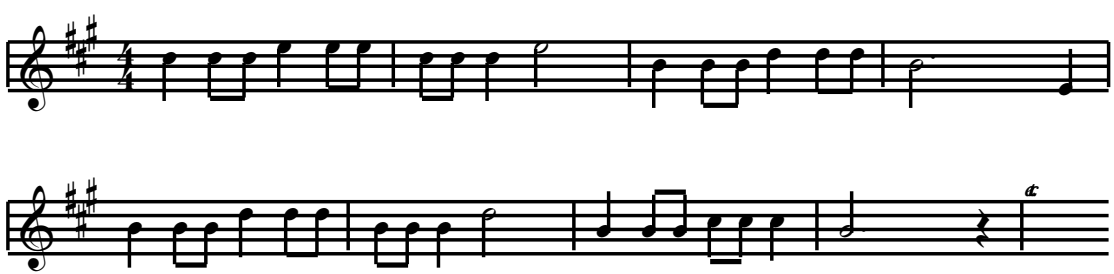

\section{Feetjieland}

Hompie Kedompie sit op die wal Hompie Kedompie het afgeval Want Hompie Kedompie is ' $n$ alkolis Dis hoekom hierdie liedjie hier is

En dit is alles waar, Ja, Dit is alles waar

Want dis in Feetjieland waar alles nie meer so lekker gaan

En dis in Feetjieland waar almal dronkverdriet verstaan

Dis waar ons mos glo, daai wonderlike plek,

Dis daar in Feetjieland

En Jan klim 'n vreelike boontjierank

Die rank is baie baie lank

Hy kom by 'n reus wat sê

Ek wil nou nie vir jou jok

Maar jy't pas die osoon opgefok

Moenie klim nie, moenie meer klim nie ...

Hansie en Grietjie het uit die bos verdwyn

'n Pedofiel het pas in die hof verskyn

Die ouvrou in die skoen-almal is dood

Dit was 'n familiemoord

En drie varkies, hulle het getrek uit die streek

Daar's net te veel by hul ingebreek

En die slapende skone,

jy weet haar prins is na die maan

Ja, hy't ook aan AIDS doodgegaan

En die res van Feetjieland het verdwyn

Daar was net te veel verdriet en pyn

Selfs kleine duimpie, ja hy moes 'n nuwe

loopbaan kies

Klein duimpie se naam is nou F. W. de Vries.

\section{Fairyland}

Humpty Dumpty sat on the wall Humpty Dumpty had a great fall 'Cause Humpty Dumpty is an alcoholic That's what this song is about.

And it is all true, Yes, It is all true

Cause in Fairyland things are not going so well now

And it's in Fairyland that everyone knows hangovers

That's where we believed, that wonderful place

It's there in Fairyland

And Jack climbs a terrifying beanstalk

The stalk is very very long

He gets to a giant that says

I don't want to lie to you

But you've just fucked up the ozone layer.

Don't climb anymore, don't climb anymore ...

Hansel and Gretel have disappeared out of the bush

A pedophile recently appeared in court

The old woman in the shoe-everyone is dead It was a family murder

And three little pigs, they moved out of the region

There's just been too much breaking in

And the sleeping beauty,

you know her man's gone to the moon

Yes, he also died of AIDS

And the rest of Fairyland has disappeared There was just too much sadness and pain Even Tom Thumb had to choose a new career

His name is now F. W. de Vries. 
Revivals as a form of cultural elevation were prominent in the eighties. Simple folk songs were transformed into elaborate arrangements for orchestra and choirs, like Van der Spuy's versions of "Bobbejaan Klim die Berg" (Baboon Climbs the Mountain), "Die Afrikaanse Pop" (The Afrikaans Doll) and "Dis Julle wat die Wind" (It's You that the Wind). The patriotic "My Land Suid-Afrika," for example, is arranged for large orchestra and massed choirs. It is deliberately reminiscent of the dramatic Wagnerian instrumentation in Tannbauser (Melville van der Spuy, pers.com. 1993), superimposing rousing descending motifs in the strings and winds over the choral theme (Example 2).

While numerous European melodies had long been appropriated into the folk repertoire ${ }^{17}$ the trend in the last years of apartheid also moved towards translating well-known European works into one of the indigenous languages. Parts of Mendelssohn's Elijab and Verdi's "Slave Chorus" from Nabucco were translated into Afrikaans by Van der Spuy, Sam Shabalala translated the Handel's entire Messiab into Zulu, and the Performing Arts Council of the Transvaal performed Mozart's Magic Flute in Xhosa. These performances served to both legitimize and elevate the vernacular.

A final observation needs to be made concerning the idiosyncrycies of revivals as forms of legitimization and elevation. The anthropologist Ernestine Friedl observed that in complex societies (where the natural process of development is unimpeded), groups of lower prestige constantly emulate the behavior of groups of higher prestige. She termed this phenomenon "lagging emulation" (1964), suggesting that the emulation takes place as the group holding higher prestige is moving away from a form of behavior. This observation seems to be not only extremely valid, but also startlingly useful to our own inquiry in revealing what I would term the "ret-

Example 2. Van der Spuy: "My Land Suid-Afrika"
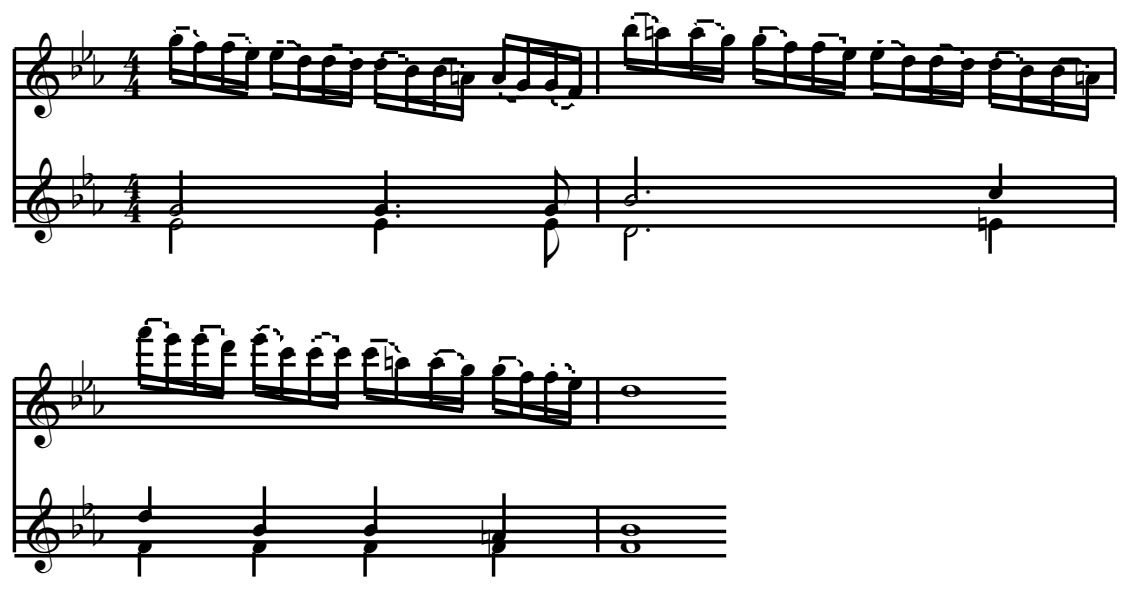
rospective emulation" that occurs in complex societies who have experienced an "arrested" development (through a historical upheaval such as invasion, or an imposition such as colonialism). The imitation of behavior is different not only from a point of view of direction (in that it is "retrospective" as opposed to "lagging"), but also from a point of view of who is imitating and who is being imitated. Lagging emulation involves the emulation of the group of higher prestige by the group of lower prestige, while retrospective emulation involves groups emulating either the old elements of their own group, or the past elements of groups of lower prestige. In this way emulation achieves all the objectives of revivals.

\section{Music as Mediator: Towards Practical Communication}

The art constituting the essence of a nation is born of the needs of that nation, and is of the very substance of all who experience the collective crisis. (FischerDieskau 1976:14)

The collective crisis that South Africans were experiencing in the final years of apartheid prompted the conception of numerous creative strategies towards intercultural communication. A prominent and influential musical force during the democratization process was the fusion music that had come into its own by the mid-1980s. Sanctions, boycotts, and the blacklisting of international artists played a vital role in the development of music at that time. Music became a primary site, both physically and creatively, for intercultural collaborations. Physically, the multi-racial club venues, festivals, and campus tours provided a meeting-place for audiences and musicians to participate in crossover genres. ${ }^{18}$

Creatively, people of all backgrounds were swept up in the growing appreciation for, and power of, syncretic styles. This trend had begun in the 1970s already with bands like Harari and Molombo, became locally prominent with the success of individual collaborations like that of Johnny Clegg and Sipho Mchunu of Juluka in 1980, and of course became internationally visible with the collaboration between Paul Simon and Ladysmith Black Mambazo in the 1986 Graceland album. "Bands such as Sakhile, Bayete, Sabenza, and Johnny Clegg's Savuka-as well as countless others, many of them less well known-played music in which that blend might be mbaqanga with traditional Nguni song; Cape Coloured klopse idioms with bebop; marabi with electronic rock; Zulu guitar style with Cape Malay ghommaliedjies; or many other permutations. It is what these integrations discovered and made possible that was exciting and important, for, like their audiences, the bands were wholly non-racial, rejecting in their behaviour and commitment, centuries of racial and class dichotomy. Their music was an alchemy, helping, in its way, to corrode the old social order and to liberate the new" (Ballantine 1993:9). 
The intricacies of sound and song texts illuminated broader issues such as clashes of values, as well as interpersonal conflicts and consensus. These multilayered texts can be analyzed to reveal explicit and implicit expressions of individuality and collectivism. They can further illuminate where the intersections lay between the individual and the group, and how these overlaps occurred so that individuals could hold membership in numerous groups, juggling a self image of wholeness and fragmentation in a complex society.

Musical fusions were actualized in five ways. First, there were the collaborations between two or more individual musicians from different musical backgrounds. The earliest and most well-known of these collaborations was between Johnny Clegg, a white anthropologist playing primarily folk music, and Sipho Mchunu, a Zulu domestic worker who played guitar and composed songs based on music from his rural village. ${ }^{19}$ Together they formed the group Juluka, and laid the foundations for similar collaborations between diverse individuals. While early combinations reflected those of the Clegg-Mchunu team, later collaborations were purposefully extreme in their historical separateness of style. For example, in the song "Father" Nico Carstens, an Afrikaans accordion player and a key figure in the boeremusiek community, teamed up with Ray Phiri, a black guitarist and singer in the group Stimela, creating an unusual blend of cross-cultural components. Similarly, luisterliedjie artist Coenie de Villiers collaborated with bass guitarist Sipho Gumede, formerly of the band Sakhile, in "Song vir Sipho."

Second, fusions were achieved through the juxtaposition or superimposition of two songs from different musical genres. The most pertinent example is Coenie de Villiers' Afrikaans luisterliedjie "Sien Jou Weer" fusion with the Jubilee Singers' version of the Shangaan work song "Shosholoza," merging two well-known songs from historically diverse cultural backgrounds. Included in this group are the juxtaposition or superimposition of two anthems that were symbolically and historically representative of different ideologies. The official anthem of South Africa, "Die Stem van Suid-Afrika" (The Call of South Africa), was discovered to be remarkably compatible with the banned African anthem "Nkosi Sikelel' iAfrika" (God Bless Africa) when superimposed harmonically or woven together. From as early as the sixties, composers have merged the two themes symbolically to suggest cultural fusion and ideological harmony (Example 3). Hubert du

Example 3. Fusion of anthems

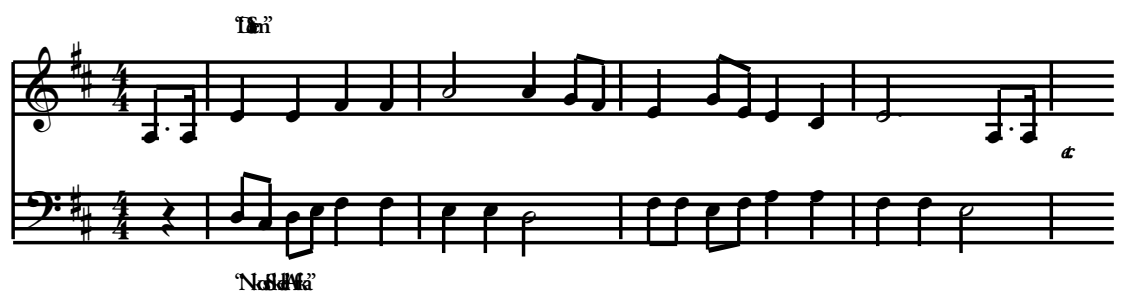


Plessis first fused the melodies in 1966, and since then numerous composers have superimposed the anthems in symphonic works. Carl van Wyk's Overture for a Festive City: Johannesburg 100 Years contains a footnote in the score which stresses that the rhythmic identity of each theme be "scrupulously maintained" so that the effect is rather more that of two interweaving themes than a harmonic counterpoint. Christopher James's Missa Sancti Bernardi, similarly, contains a clear fusion between the two anthems.

The third form of fusion was between two or more styles or genres within a single work. This form is the most common, as it lends itself to wide lendings and borrowings between styles in general. Johannes Kerkorrel's song "Awuwa" juxtaposes the European folk song style with African rhythm, and code-switches (see below) between the Dutch lyrics of Stef Bos, the Afrikaans responses of Kerkorrel, and the phrases and vocal calls of the African jazz singer Tandie Klaasen. The signature song of the musiek en liriek era, written by Koos du Plessis and entitled "Kinders van die Wind," was re-arranged on Laurika Rauch's Hot Gates album to superimpose a cyclical mbaqanga rhythm over the original lilting guitar accompaniment (Example 4).

A particularly fertile area of genre fusions could be found in symphonic works that incorporated instrumental, harmonic, rhythmic, or thematic African elements. Ali Rachbari's Half Moon, for example, contains a grand finale in which the theme from Beethoven's Nintb Symphony is enhanced in the descant by the cyclical chant of an African chorus (Example 5). Numerous "ethnoclassical" composers have contributed to this growing repertoire of syncretic styles with works like Carlo Franci's African Ora-

Example 4. "Kinders van die Wind"

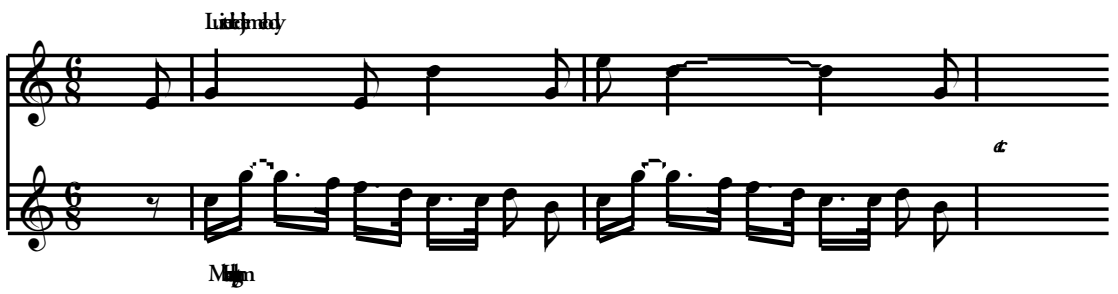

Example 5. Rachbari: Half Moon

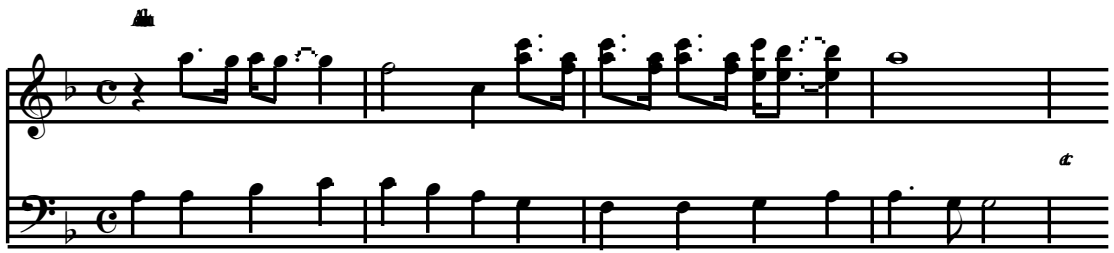

Rhostyptoy 
torio, Hans Roosenschoon's Mantis, Kevin Volans's White Man Sleeps, Stefans Grove's Nonyana: The Ceremonial Dancer, Jeanne ZaidelRudolph's Music of the Spheres, and Christopher James's Images of Africa. Syncretic works with political overtones include David Hoenigsberg's Threnody for the Victims of Boipatong and Soweto 1976: Sonata for Double String Orchestra and Percussion and John Simon's Threnody for Steve Biko. Many of the composers of these "ethnoclassical" works are involved in a lively academic discourse concerning the agendas of such works. The trend has become an increasingly contentious one, especially concerning the motives behind the sudden escalation of works using "reconciliations" of Western and African components (see Levy 1986; Roosenschoon 1992; Eichbaum 1993; Taylor 1995; Byerly 1996). The fusion of symphony and jazz became highly visible with Abdullah Ibrahim's celebrated performance of his Jazz Concert, while the Soweto String Quartet popularized the fusion of the western string quartet and traditional African songs with their albums entitled Zebra Crossing and Renaissance.

The fourth and final strategy of collaboration was through a complete fusion of musicians, styles and languages from different backgrounds within syncretic or fusion bands. Among these are groups like Orchestro Mondo, Marimba, Intsholo and Mosaic. The works of many fusion groups are characterized by rich superimpositions of not merely musical components like melodies, harmonies, rhythms, and instrumentations, but also by juxtapositions of linguistic components in the form of frequent code-switching.

\section{The Use of Code-Switching}

Through the skilled use of linguistic gymnastics, crossing over between various languages within single songs, albums or performances, musicians showed themselves to be culturally and socially competent within and across particular societies. They also displayed knowledge, sensitivity, insight, and skill in relation to the unspoken rules and ethics contained within the communication skills of speech communities, especially multicultural and multilingual speech communities such as the ones in South Africa. They recognized the importance of being not only linguistically versatile, but also capable of switching between relevant and appropriate speech genres and codes. Linguistic competence played an enormously important role in crosscultural communication within music in the late-apartheid era. The specific reasons for code-switching between different languages are, of course, as varied as the incidents themselves. Making provision for the social comfort and comprehension of not only oneself (amidst the myriad of potential meanings and potential offenses), but also of the group, is directed through efforts to "save face," whether one's own or somebody else's. The careful recognition of what Brown and Levinson (1978) call FTA's (Face-Threaten- 
ing Acts) became a prerequisite for the musician to feel culturally competent through linguistic versatility. Code-switching itself was armed with enormous social power in terms of its use or even its misuse. It could even be used as a subtle strategy to flatter or offend. Another use of an FTA was to soften code-switching and turn it into a joke, obviously by switching codes to one in which a listener would feel privately or humorously included. In the case of musicians and the use of music in South Africa, an interesting angle has been added to the notion of the FTA. In numerous cases codeswitching was not to "save face" but, on the contrary, to express an "in your face" sentiment. Using a word in a particular language (within the context of another language) to make a dig at a certain group, or to target that group through the use of their linguistic code, was an effective way of getting attention from the individuals of the group concerned, as well as revealing that a particular reference is pointed. Simple examples, such as the reggae artist Lucky Dube's reference to the cruelty of "die polisieman" (where the policeman is suggested to be Afrikaans through the use of a single Afrikaans article and noun within an English sentence), is an example of "in your face" code-switching. During the Afrikaans alternatiewe beweging, the juxtaposition of English words within Afrikaans songs were specifically placed to send a message to Afrikaans purists who were annoyed by the use of "other" vocabulary in Afrikaans sentences. The temptation to play on this annoyance was, of course, too great for the likes of the controversial "alternatiewe Afrikaners," and their songs contain so many slang English words that many of them could be called almost bilingual.

Musicians whose primary agenda is inter-cultural collaboration, or national reconciliation, like the group Another Friend in Another City, use code-switching to involve as many people in their audience as possible. They tend towards using direct translations within their songs, repeating and stressing phrases in more than one language not only to be more inclusive, but also to stress certain issues through code-switched repetition. One of their songs is titled in two languages: "Thula Sizwe: I Shall be Released" and their song entitled "Umkhululiwethu" has alternate verses in different languages. Code-switching therefore also manifested itself on a larger scale through the use of complete songs in various languages within a single performance or album. Albums would also have some song titles in one language, with different verses or a chorus in another language. Mango Groove's Hometalk album, for example, has songs like "Marabi Party," "Uzongikhulula," and "Shoo-Roop!" Code-switching, then, has primarily been used as a means by which people are included or excluded from understanding the lyrics of a song, and as such reshuffles the boundaries of group membership. Like musical themes, some expressions are recognizable and translatable, while others are not. This phenomenon fur- 
ther contributes to the notion that music and lyrics can be used as a vehicle for social collaboration or social mobilization. The musician Sazi Dlamini put it clearly when he said that there are "some people you want to alienate, through the use of music they don't identify with, in order to point out certain tensions" (pers.com. 1996). While the objective of the music indaba was primarily to resolve tensions, it often served as an arena within which these tensions could be confronted. The musical debate could therefore be heated without being physically violent.

Collaborative music not only served as a unique and powerful form of inter-cultural communication, but in retrospect it provides an analyzable discourse within which to observe the trends of the transition period. The musician Sipho "Smile" Nkosi said of these multiple influences that "our music can be unthreaded like a jersey [sweater]" (pers.com. 1993). He suggests that the many influencing "voices" are woven together in a counterpoint that allows for the maintenance of their individuality, while contributing to the harmonious intention of the piece as a whole.

While music contained numerous voices that could reveal complex social discourses challenging the social dynamics in the country, the third purpose of music was to confront political and legal issues. This was achieved not merely through the content of the music itself, but also through the tireless struggles of musicians to create environments where their performances could be heard by all audiences, regardless of race. "We didn't let up on the government to abandon racial laws in the theatre. We convinced them that theatre was simply where performers face audiences and audiences face performers. Would you understand if I told you that they regarded people who went to the theatre as a lunatic fringe who were relatively harmless? So legislation changed. And the common thread all the way was music." (Des Lindberg, pers.com. 1994).

New musical innovations managed to profoundly destabilize the restrictive nature of state-controlled social interactions. Songs and venues served as both artistic and geographical sites for communication between groups, and this trend became an increasing threat to the government in enforcing what was termed "separate development," a notion central to apartheid ideology. Although over two millenia old, Plato's statement concerning the political influence of music is still pertinent to present-day governments: "Any musical innovation is full of danger to the whole State, and ought to be prohibited; when modes of music change, the fundamental laws of the State always change with them." (The Republic).

While referring to the control of ancient States, the words still hold true for those of modern Republics, and in the Republic of South Africa the innovations of the music indaba were mobilizing great changes through both protest and prophesy. 


\section{Music As Prophet: Towards Tactical Mobilization of Change}

Music is prophesy. Its styles and economic organization are ahead of the rest of society because it explores, much faster than material reality can, the entire range of possibilities in a given code. It makes audible the new world that will gradually become visible, that will impose itself and regulate the order of things: it is not only the image of things, but the transcending of the everyday, the herald of the future. For this reason musicians, even when officially recognized, are dangerous, disturbing and subversive; for this reason it is impossible to separate their history from that of repression and surveillance (Attali 1992:11).

One of the most significant achievements of music in the late-apartheid era was the ability to sound a prospect of the future. This music suggested intercultural collaborations that may not have existed socially at that stage, yet in doing so, it brought them into being through their vision. It suggested political developments that may have seemed unimaginable at the time, yet in doing so, it signaled their arrival. While music and theater had earlier in the century been seen as the harmless domain of a "lunatic fringe," it became increasingly apparent what power lay in themes played and sentiments sung.

An interesting case reveals music as momentarily taking on the role of "false prophet" in the democratization process. In August 1986, a scandal erupted in South Africa following the release of a song entitled "Together We Will Build a Brighter Future." The problem lay not so much in the ideologies expressed in the song (many artists having recorded conciliatory lyrics) as in the source of the song. It was released, to great fanfare, as the official "Peace Song" by the government's Information Bureau. As part of their "Operation Optimism," the Bureau had done market research to find the most effective medium to relay a message of cooperation at the height of the unrest in the country. They wanted to springboard "a promotion of peace, progress, and prosperity" through a vehicle that had proved itself to be the most immediate form of communication with the greatest impact on as wide an audience as possible. Music proved to be that medium. Fortyseven prominent musicians were hired to record the song (much in the vein of Live Aid's song "We Are the World") in seven languages: English, Afrikaans, Zulu, Xhosa, Sotho, Tswana, and Pedi.

There were numerous objections to the release of the song. Taxpayers were angry that 4.3 million rands had been spent on a project that was seen as a propaganda whim. Members of the public were angry that, at the height of an emotionally-charged political situation, the government was attempting to dictate public sentiment through a public medium without public initiation. They were further angry that the song belied the present political realities in the country, attempting to camouflage a crisis with 
pacifying rhetoric in the hope that people would be lulled into a sense of false security with the government as patriarchal overlord. Musicians were particularly angry that their sacred ground had been usurped by the very camp against which their music was most fervently and effectively being targeted. Their one medium of creative initiative had not only been exposed, but more crushingly, appropriated by the target of their cultural weapon. A considerable amount of friction developed between musicians who had previously seen themselves as kindred spirits in the struggle, and who now suspected a division between those involved in the project (seen as government pawns, or "sellouts") and those not involved (seen as the true protest artists). Those less critical of the project, seeing the unifying sentiment behind the song as a worthy one, merely criticized the fees the musicians involved had been paid for their services. In support of the project, a spokesman for the bureau claimed that "Music of the heart is not born. The groundwork must be laid in political chambers by courageous statesmen that can lead the occasionally stubborn voter. A song can help oil the wheels" ("Die Rapport," 26 August 1986:6).

The doomed Peace Song of 1986, needless to say, was stillborn. Using characteristic religious imagery, one newspaper commented that "That which is conceived and born in sin will be fit for no good" (Die Transvaler," 4 November 1986:21). The release was a non-event, boycotted by the public, and by December 1986 all copies of the song were recalled prior to any commercial sales. Musicians and the listening public alike were left disillusioned and disgusted that music had become part of party politics. In an opinion poll conducted over the debacle, it was found that a Peace Song would have been overwhelmingly supported had it been composed at a time when the prospect of peace was less forced. It also needed to be the result of creative inspiration on the part of musicians and the public themselves; a grass-roots, public-initiated effort from the "bottom up" as opposed to a government-initiated project commissioned from the "top down." It needed, in short to be "music from the human heart, not the politician's head" (Sipho "Smile" Nkosi, pers.com. 1993).

To date, resistance and protest music had been solely the domain of the human heart, not the politician's head. The first half of the century presented a constant flow of resistance and protest music, almost entirely from the disenfranchised black community:

There's no saying when the first freedom song was sung in South Africa, but certainly one of the most significant was Enoch Santonga's 'Nkosi Sikelel' iAfrika' . . There were songs about education, anti-pass songs performed during the passive resistance campaign of the 50's. These include 'Mayibuye Afrika' (Come Back Africa) sung to the tune of Clementine, one with the words 'Jan van Riebeek has stolen our freedom,' the still popular 'Abelungu Goddam' 
(Goddam the Whites) chant, 'Thina Sizwe' ('We Africans! We cry for our land and they took it. Europeans must let our country go.') Another was 'Hey Malan! Open the jail doors. We want to enter. We volunteer ... ' Possibly the best known songs from these times were those sung by the women in the campaign against passes . . . the warrior's song of the women of Natal (had) new words: 'Strijdom, you have struck a rock once you have touched a woman; you have dislodged a boulder, you will be crushed.' . . . Chanted slogans have always been used in South Africa to give direction and inspiration to those involved in one way or another in resistance against the state (Anderson 1981:31-32).

The second half of the century (especially after 1960) saw a growing body of white artists involving themselves in anti-apartheid musical endeavors. Ironically, while the government was at first unconcerned with this "lunatic fringe," it turned out to be far more dangerous to the state than was being recognized. Insiders were in fact "breaking rank," and in so doing, they were effectively eroding the invulnerability of the system. While the first wave (of resistance) may have served to illuminate injustices, it was only with the second wave (of protest) that the music indaba came into its own as a powerful social movement, involving all sectors of the community, to mobilize change collaboratively. Song texts presented rich commentaries on how diverse communities were reacting to the dynamic changes and pressures of the era, and provided unique insights not only into the dilemmas of the process, but also into a reinterpretation of the notion of "resistance." More importantly, these texts provided sites within which the unsayable could be said, and where contentious issues could be explored without hazardous consequences.

Mbaqanga artists like Mahlathini and the Mahotella Queens, while not considered "protest" musicians, provided insights concerning the communities in the townships. While being unconfrontational, they revealed a reality that, through their revelation, appealed for resistance to the status quo. Folk singers in white communities, meanwhile, began to perform songs like "Immorality," "We Shall Overcome," and "I was Born Pitch Black" to confront the newly stringent censorship laws, but these were quickly banned. The involvement of the international music community became apparent with the release of Peter Gabriel's "Biko." It was a particularly important song, for although it was banned in South Africa, the numerous bootleggings distributed in the country reflected the unique ability that music had to carry information and political messages that were otherwise suppressed in the media. "Biko" was the song that also alerted the international music market to the seriousness of the South African situation, and it was followed by further musical endeavors against apartheid, like Little Steven's Sun City album, the Special AKA's Free Nelson Mandela, Harry Belafonte's Paradise in Gazankulu, and the 1988 "FreedomFest" at Wembley, London. 
Political songs and social commentaries, especially those utilizing subtle strategies to mislead the censors, became prominent in local releases. Some artists, like Mzwakhe and Lesego Rampolokeng, leveled stinging critiques at the government, and were still frequently banned. Others utilized their music to reveal stark realities of their relationships, like the reggae artist Lucky Dube's "My Brother, My Enemy" and their visions of their world, like the alternatiewe Afrikaner Kerkorrel's "Donker Donker Land" (Dark Dark Land) and Koos Kombuis's "Babilon Blues." Music was particularly used to promote resolutions to the conflict, as in Chicco's "Modjadji," Ray Phiri's "People Don't Talk," and Sankomota's "Stop the War," as well as to prophetize optimistic visions of the future and of ideological imagined communities, like Bayete's "Celebrate Life," Savuka's "One Man, One Vote," and Ray Phiri's "One Heart, One Nation, One Mind."

A final musical strategy used for powerful commentary on political and social realities was the contentious adaptation of anthems; whether the official national anthem ("Die Stem") or the banned African anthem ("Nkosi Sikelel' iAfrika"). Their fusions and manipulations served as the basis for numerous insightful introspections. None was more critical than Koos Kombuis's song "Swart September" (Black September), based lyrically on the much-loved poem "Oktober is die Mooiste Maand" (October is the Loveliest Month) by Afrikaner poet Louis Leipoldt. While presenting a sinister variation on the original poem, and a strikingly pessimistic contrast to the optimism of the lyrics of "Die Stem," Kombuis presents the reality of South Africa as a dark and dreadful place, compared to the rosy Nirvana that Leipoldt suggested in his poem shortly after the turn of the century. While October months may have been filled with optimism for a small sector of South African society, September 1984 was a month of intense tension. Suppression of all signs of unrest or uprisings in the townships, a trend which eventually led to the explosive Uitenhage riots of 21 March 1985 (twenty-five years to the day after Sharpeville), resulted in a national State of Emergency. The melody of the chorus, although recognizable, is adapted to present a more melancholy tone than the more triumphant melodic progression of "Die Stem." By compressing the melody to within the range of a third (instead of the sweeping arpeggio across an octave) and changing from a major to a minor key, Kombuis presents a musical parallel to his lyrical suggestion of doom and disaster (Example 6). The lyrics of the song, a concertedly morbid variation on the patriotic words of the original anthem, are thick with double meanings and ominous symbolism. Furthermore, cruel cynicism juxtaposes images of good times and easy living (which permeated the earlier Afrikaans poetry and song) with horrific pictures of violence and squalor in the country. Simple pleasures and optimism of the early poem are placed against large catastrophes, and there are nu- 
Example 6. Variation on the official anthem
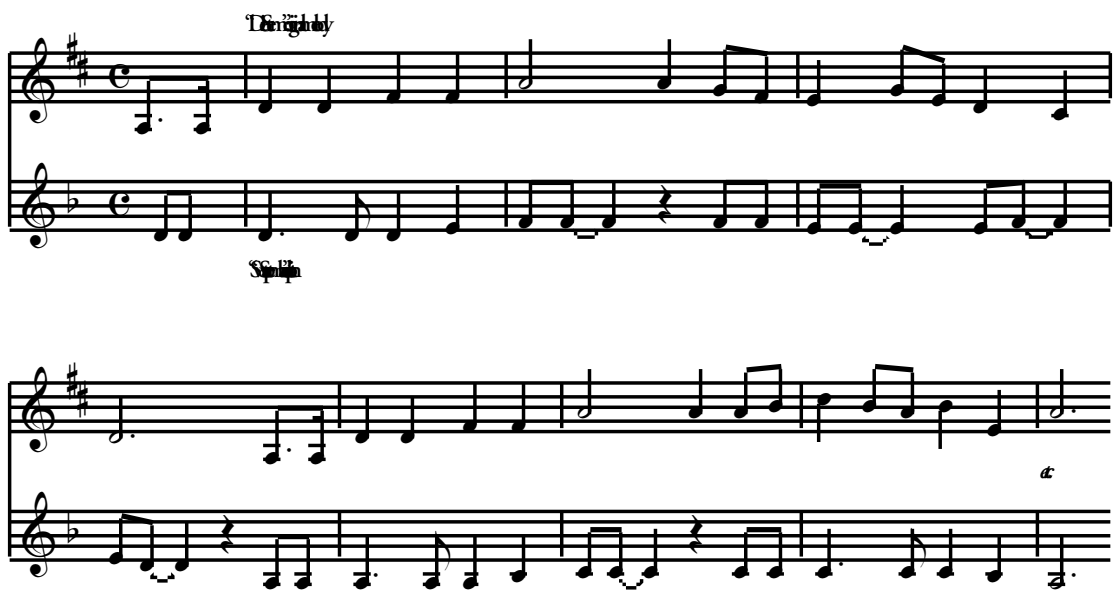

merous plays on words, such as the word treurnicht, which refers to both the direct translation "weep not" and the name of the conservative political leader Andries Treurnicht.

In the wake of censorship, the need for subtlety was imperative. The ingenious superimpositions of the official South African and the unofficial African anthems frequently slipped through official scrutiny, and sent a strong conciliatory message. In the mid-1980s the group Bright Blue brought out the song "Weeping," which risked using the banned African anthem as an inconspicuous theme in the bass of the song. To the astute audience it was obvious; to those listening to the song as harmless pop it was hardly audible. The song became an anthem itself in the underground world of the clubs, and many bands covered it-some accentuating and some hid-

Die Stem Van Suid-Afrika

(Original Lyrics)

Uit die blou van onse hemel

Uit die diepte van ons see

Oor ons ewige gebergdes

Waar die kranse antwoord gee

Deur ons ver verlate vlaktes

Met die kreun van ossewa

Ruis die stem van ons geliefdes

Van ons land Suid Afrika

Ons sal antwoord op jou roepstem

Ons sal offer wat jy vra

Ons sal lewe, Ons sal sterwe

Ons vir jou Suid-Afrika
The Call of South Africa

Out of the blue of our heavens

Out of the depth of our seas

Over our eternal mountains

Where the crags echo

Over the vast uninhabited valleys

With the groan of oxwagons

Raise the voice of our beloveds

Of our land South Africa

We shall answer to your call

We shall offer what you ask

We shall live, We shall die

We're for you, South Africa 
Swart September

(Alternatiewe Adaptation)

Uit die blou van ons gekneusdheid

Uit die diepte van ons heimwee

Oor ons ver verlate homelands

Waar die tsotsis antwoord gee

Oor ons afgebrande skole

Met die kreun van honger mae

Rys die stemme van die squatters

Van on land Azanie

Ons sal traansgas, Ons sal treurnicht

ons sal offer wat jy vra

Ons sal dobbel in Sun City

Ons sal suip vir Afrika

\section{Black September}

Out of the blue of our bruisedness Out of the depths of our nostalgia Across our far deserted homelands Where the gansters give answer Over our burnt-down schools With the groan of hungry stomachs Raise the voices of the squatters Of our land Azania

We shall teargas, We shall weep not We shall offer what you ask We shall gamble at Sun City We shall drink for Africa.

ing the theme in the bass. It was a long time before the message was received by the authorities, and the song was banned immediately when the subversive content was recognized. There were also some renditions that were confrontational, like the rap version of "Nkosi Sikelel' iAfrika" by Prophets of da City. The lyrics of the song focused around reclaiming what had been usurped, with the anthem weaved in between aggressive phrases, punctuated by cries for black power. In the rock world, as in the ethnoclassical world, musicians had long recognized the harmonic and rhythmic compatibility of the two themes. Not only were they juxtaposing the themes, usually in canonic form with one voice entering after the other, but some were even superimposing the words of one anthem onto the melody of the other. Dan Moyane, a popular radio announcer, released a CD single using this superimposition of the words to "Nkosi Sikelel' iAfrika" over the tune of "Die Stem." 20 The suggestions of symbolic social fusions were obvious, and the rendition was seen as ingenious, shocking, discomforting, and even satirical (Example 7).

When apartheid ended and "Nkosi Sikelel' iAfrika" also became an official anthem, many musicians and non-musicians commented on the strangely profound significance that both anthems took on with the inauguration of Mandela. Overnight, the subversive anthem became patriotic, and the unacceptably underground overtones of the music were instantly replaced by publicly acceptable connotations. Interestingly, not only did

\section{Example 7. Superimposition of anthemic words and melody}

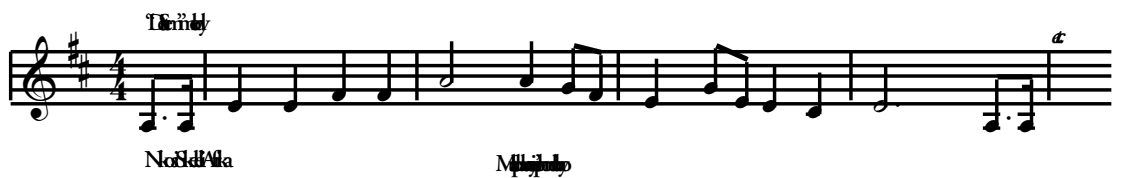


the African National Anthem "Nkosi Sikelel' iAfrika" take on a new meaning, but so too, remarkably, did "Die Stem." Contrary to many expectations, the old Afrikaans anthem did not suddenly take on the sinister connotations of old racism of the old regime, but rather of a collaborative effort towards a new order. When F. W. de Klerk handed over his presidency to Nelson Mandela, he ended his speech in Xhosa with the words "Nkosi sikelel' iAfrika" (God bless Africa). This was followed by the first singing of the new and the old anthems in their newly-combined official capacity. Nishlyn Ramana, pianist in the group Mosaic, believes (as do many) that it was because "the moment symbolized both liberation for Whites and affirmation for Blacks. 'Nkosi' became movingly relevant, and 'Die Stem' suddenly meant what it was supposed to mean all along. They both took on a profoundly new significance" (pers.com. 1995).

In March 1993 a Peace Song entitled "Peace in Our Land" was released amidst great expectation and celebration. Mandela was a free man, and it was just a year before the final elections of the democratization process were to take place. The musician who composed the song, Sello Chicco Twala, announced that "The time is ripe for a peace song. Political leaders are freed and exiles are returning. But we must have peace before we can be truly free" ("Die Beeld," 12 March 1993:6). At the cost of R70,000 (a fraction of the government-sponsored "Peace Song" of 1986), the privately-sponsored venture was part of a public initiative calling themselves the "National Peace Committee." All financial gain from the song went to the newly-created "Victims of Violence" fund. Using the Soweto Children's Choir and forty professional musicians who had previously all been involved in separate musical ventures promoting inter-cultural communication, the song received extensive airplay and overwhelming commercial support. ${ }^{21}$ It had passed all the public criteria for the acceptance of a national "Peace Song." First, it was not initiated by the government, and it was unaffiliated with any political party. Second, it did not use taxpayers' money, and artists contributed their services freely. Third, the lyrics were not the result of political propaganda, but rather the fruits of creative initiative on the part of an artist in collaboration with his community. And finally, the song was written "from the human heart, not the politician's head." So successful was the song that within a few weeks a R70,000 return on the initial production costs was handed over to the "Victims of Violence" fund. On 2 September 1993 an official "Peace Day" was held throughout the country to celebrate the significant decline in violence over the last six months, and at noon on that day all radio and television stations throughout the country observed two minutes of silence, followed by the playing of the Peace Song. Music had voluntarily been proclaimed the medium of the people, not through market research, but through artistic contribution and public reception. 


\section{Conclusion}

Through the music indaba, South Africans used interesting musical strategies to achieve various objectives throughout the democratization process. In a society fraught with the tensions of state control, censorship and rapid change, music represented the eye of the storm: both in the sense of a safe haven and as the center of controversial discourse. Even in the wake of stringent coercion (through strong censorship and enforced propaganda), these objectives were accomplished through cooperation (to express identities, convictions, or affiliations), through collaboration (to forge relationships and to renew affiliations), and through co-ordination (to express resistance or protest).

Music created for symbolic purposes (for the re-assertion of identity) was presented through four objectives: cultural renaissance, historical review, cultural critique and cultural elevation. Music created for practical purposes (for intercultural communication) was presented through four forms: collaborations between individuals, fusions between songs or anthems, combinations of genres, and collaborations between groups. Music created for tactical purposes (for political mobilizations and social change) was presented through dynamic dialogues exploring political issues of a confused past, an unstable present, and an envisioned future.

Music's power lies particularly in its mobility. It is transported not merely through localized diffusion, but also through geographical leaps of innovation. It is also easily absorbed, easily woven through styles and genres while influencing and reflecting dynamic cultural and intercultural developments. Music can express and engage a multitude of diverse voices simultaneously, and is not accessible only to those born into a genre. As the saying goes, one does not have to be a deaf Bavarian to appreciate Beethoven, or a blind Protestant to understand Milton. Just so, one does not have to be disenfranchised Zulu from Soweto to appreciate the kwela pennywhistle style, or a classically-trained Afrikaner from Pretoria to appropriate an ethnoclassical composition style. ${ }^{22}$ The success of the collaborative movement was, in fact, largely dependent on the "crossing of borders" (into unknown personal spaces) and from pointedly "breaking rank" (from the comfort of a known group). It is for this reason that the trailblazers moving in both directions deserve recognition-not necessarily for the lasting value of their musical aesthetics, but for mobilizing change in a moment when their art could be instrumental in that change. The tendency for protest artists' work to become cliched or passe in retrospect is great, and this is all the more the pity, for they served their purpose when their purpose was most needed. ${ }^{23}$

Music provides analyzable discourses which reveal the paths of people's histories, and traces the soundscapes of societies as they move through their 
dynamic development, simultaneously often presaging their futures. It illuminates the complexity of the voices within particular social groups and follows the paths of small societies as they appropriate, and in turn influence, elements of the larger societies around them. It facilitates the revelation of the rural village's connection with the urban village, which in turn sounds its part in the global village. While the urban village is often merely the startled, disconnected dueling point between a seemingly bounded rural village and an optimistically united global village, music presents a particularly fertile area of inquiry through the contradictions and complexities of sound between these transitional stages. It is in these transitions that the tranquil rural folk song becomes the provocative urban pop song, which in turn becomes the reconciliatory world music. Music also manages, like few other discourses, to contain various phases of time in the moment of its execution. It can borrow from the past to actualize the present, while predicting the future, and it can utilize the past to reveal the present while creating a future. It can mirror while mediating, and mediate while prophetizing. Music is the ultimate expression of self, the ultimate communicator, and the ultimate harbinger of things to come-both for those who create music and those who are the inspiration and audience for musical creations.

Fanon quotes Sekou Toure in asserting not only the importance of sincerity and collaboration in the use of art forms in resistance movements, but also in the way these art forms will serve as "awakeners" for others in the success of the movement (Fanon 1961:206):

To take part in the African revolution it is not enough to write a revolutionary song; you must fashion it with the people, the songs will come by themselves.

In order to acbieve real action, you must yourself be a living part of Africa and her thought; you must be an element of that popular energy which is entirely called forth for the freeing, the progress and the bappiness of Africa. There is no place outside that fight for the artist...

\section{Appendix: Glossary}

Alternatiewe Beweging ("Alternative Movement"): Encompasses the alternative-Afrikaner's musical resistance movement (of a "punk"-type style). It had a tentative beginning in the East Rand Rock movement of the late 1970s, and experienced its peak between 1986 and 1990, challenging previous notions of ideology and identity. Artists include Bernoldus Niemand, Johannes Kerkorrel, and Koos Kombuis.

Boeremusiek ("Boer Music"): This style had its heyday in mid-century, and consisted of combinations of the concertina, guitar, pump-organ, 
double bass, violin, and banjo. Pieces are either instrumental or with Afrikaans lyrics. Modern artists include Louis Hurter and Pierre Retief.

Boereqanga: A fusion style of the "new South Africa" containing musical components of both boeremusiek and mbaqanga. Influential figures are Henry Shields, Nico Carstens, and Ray Phiri.

Ghommaliedjies: Light "picnic" songs derived from a fusion of Malay and Afrikaans handdrum and song influences from the early twentieth century.

Ethnoclassical: The syncretic fusion of South African traditional (Nguni and Sotho) music elements with classical art music components. Composers include Hans Roosenschoon, Stefans Grove, Jeanne Zaidel-Rudolph, John Simon, and David Hoenigsberg.

Isicathamiya: Zulu a cappella choral music style consisting of call-andresponse between a lead singer and chorus (usually male). This form became popularized with the song "Mbube" (also known as "The Lion Sleeps Tonight" or "Wimoweh") and since then the form itself is often called mbube. The group Ladysmith Black Mambazo is a proponent of the style.

Kwela: Township and urban music dominating the 1950s and highlighting the pennywhistle. Artists included Lemmy "Special" Mabaso and Spokes Mashiyane.

Lekkerliedjie ("Nice Song"): The blandness of the description is mimetic of the stylistic content in this genre. Musically and lyrically, lekkerliedjies are light and unchallenging; a sort of easy-listening. Lyrics centered around flora, fauna, and geographical locations to avoid controversial issues. Artists included singers like Ge Korsten and Min Shaw.

Luisterliedjie ("Listen Song"): The essence of the song lay in the poetry of the lyrics, requiring careful listening. Loaded meanings replaced bland "nice" lyrics. Early proponents of this form were Laurika Rauch, Anneli van Rooyen, and Anton Goosen.

Marabi: Music of the townships from the late 1920s to the sixties. Based on a three-chord progression, the style later developed into the more complex styles of township jazz.

Maskanda: Traditional Zulu music genre with western instrumentation like guitar, violin, and piano accordion. The term is derived from the Afrikaans work musikant, meaning "musician." Popular artists include Mbongolo and Moses Mchunu.

Makwaya: Choral music of Africans educated in mission schools, combining traditional African music elements with influences from European songs and hymns and American gospel singing. Makwaya also refers to some traditional forms of bow-music.

Mbaqanga: A "fusion" style that developed in the mid-1960s in the townships, blending earlier influences of marabi, kwela, and traditional elements. The earliest proponents of the style were Mahlathini and the Mahotella Queens. 
Sefela: Sotho sung poetry in recitative style. This form is common amongst Basotho migrant laborers, and primarily expresses human reactions to migrancy and the consequent changing personal and social situations.

Simanje-manje: Alternate word for mbaqanga. This style usually consists of lead singer and four-member choral response (often female). The earliest proponents of the style were the group Isigqi sesiManje.

Toyi-toyi: Mass slogan-chanting in the streets, particularly by crowds of black women, which became powerful expressions of protest towards the end of the 1980 s.

\section{Notes}

1. An earlier version of this article, presented at the annual meeting of the Society for Ethnomusicology in Los Angeles, was awarded the Charles Seeger Prize for 1995. I am deeply indebted to the many people who have provided their valuable insights and encouragement throughout the duration of this project. Particularly, I would like to thank the many musicians of South Africa who, during the peak of the music indaba itself, welcomed me to share the experience, and who, during my consequent analysis of the movement, spent hours of their time discussing their work. I received much guidance in the formative statges of this project from Claudia Strauss, William O'Barr, Charles Piot, and Jan Ewald. Useful and encouraging comments were offered by Chris Smith and Godwin Sadoh following a presentation of this work to the Society for Ethnomusicology at the annual meeting in 1995 in Los Angeles. I am grateful for the suggestions from Louise Meintjes, Carol Muller, and Christopher Ballantine following work on an earlier version of this paper. Paul Berliner and Kenneth Surin offered generous assistance and invaluable insights on the revised version. I would also like to thank Deon Maas (Tusk Records), Ferdie Schenk (JNS Music) and Ilse Assman (SABC) for the generous contribution of materials and time in South Africa. My thinking has been richly influenced by colleagues and friends, particularly in conversations with Rob Allingham, Lara Allen, Doris Anders, Jim Bailey, Rexleigh Bunyard, John Clarke, Richard Cock, Jacques de Vos Malan, Sazi Dlamini, Des and Dawn Lindberg, Hubert du Plessis, Stefans Grove, David Hoenigsberg, Louis Hurter, Christopher James, Debra James, Johannes Kerkorrel, Jabu Khanyile, "Nataniel" (le Roux), Michael Levy, Deon Maas, Chabani Manganyi, Sean Newman, Sipho "Smile" Nkosi, Nishlyn Ramana, Gideon Roos, Hans Roosenschoon, Lloyd Ross, Morakile Shuenyane, Alan Solomon, Warrick Sony, Vivien van der Merwe, Melville van der Spuy, Anastasia van Schalkwyk, Carl van Wyk, and Alexei Yurchak. The Ernest Oppenheimer Memorial Trust Fellowship (South Africa), a Doctoral Prestige Scholarship from the Center for Science Development, Human Sciences Researches Council (South Africa), the Sigma Xi Society for Scientific Research (USA), the Center for International Studies (Duke University) and the Aleane Webb Award Fund (Duke University) all provided funding which made this project possible, and I would like to extend my appreciation to them for their generosity. My sincerest thanks to Boyce Byerly, who provided constant suggestions, and streamlined my thinking throughout the duration of this project. All translations into English are my own.

2. Although my particular interest lies in non-violent strategies towards the democratization process, I would like to note that the armed struggle, which took the lives of thousands of South Africans fighting in the liberation movement, should not be underestimated as a powerful force behind the social and political mobilization.

3. The oversimplified divisions into "Black" and "White" have been the cause of a further serious social consequence: that of alienating groups like the South African Indians, and particularly the large mixed-race community (registered as "Coloureds"). Through this backgrounding of a "hybrid" presence, their existence has been largely marginalized in South African history. 
4. This is in line with both the Comaroffs' (1991) notion that the process is never complete, and there are always "seeds" remaining to germinate again, and Bourdieu's (1977) assertion that "orthodoxic" discourse is never capable of completely restoring a "doxic" state.

5. Although there was strong censorship of both anti-apartheid literature and music by the Censor Board of the government, numerous independent publications and record companies continued to record and distribute publications and music that were knowingly "subversive" (and often consequently banned). Even when printed matter was seized, and vinyl records had entire sections cut across by sharp objects to prevent them from being heard, the underground press and tape bootlegging activities were relentless in their perseverence. Additionally, reactionary efforts by protest artists became increasingly successful in bypassing censorship through subtle and ingenous compositional techniques.

6. The area of "sociogenic theories of mind" is particularly relevant here, and is being examined by an interdisciplinary group of social theorists, particularly scholars in anthropology and psychology (Henriques 1984; Leont'ev 1972; Valsiner 1991; Wertsch 1991).

7. These are being further explored in the cognitive sciences through avenues like networking and parallel-distributing processes and quantum physics through chaos theory and fractals.

8. The scope of what can be defined as "resistance" or "protest" music is obviously a slippery area. My concern is as much (if not more) with forms that were subtle as it is with forms that were blatant. Music that was not openly and forcefully subversive often achieved even more "resistance" (both as instigator and as receiver) through its seemingly inoffensive nature. Its expressions of innocuous issues like everyday life exposed more loaded and revealing social scenarios ("between the lines") without drawing attention to itself as form, agent or instigator. This attribute of inconspicuousness is in line with Hebdige's traits in an effective and powerful subculture (Hebdige 1979).

9. Through highlighting the differentiating characteristics of resistance and protest (as loosely defined here), I do not suggest exclusivity of these characteristics to each. They overlap to a large extent, the first containing growing elements of protest and the second still maintaining the elements of resistance it grew out of. The nominal allocation merely suggests the leanings of each, and serves as a useful means by which to differentiate the earlier from the later movement.

10. I would like to stress that I deal here with music and musicians that saw themselves as part of the reform movement. There were numerous artists not involved in this movement, whether through disinterest in it, or resistance to it. These artists, in fact, would be a fascinating subject of further investigation, as the agendas of musicians not involved in the music indaba (especially those opposed to the motives behind it) are interesting in themselves.

11. This graph presented serves merely as a spacial metaphor, and does not represent specific quantitative measurements. It can, of course, have variations of its amplitudes, depending on individual perspectives on the importance of certain historical events and their consequences on musical trends in the country. The given model suggests the intensity of activity in the form of increased participation (of both musicians and the audience), creative works, rallies, festivals, record distribution and club appearances as reactions to suppression of those activities.

12. Des and Dawn Lindberg, Keith Blundell, Jeremy Taylor and Robert Kirby were among the most notable of these artists. The achievements of this group of individuals in legalizing multi-racial performances in South Africa are, regrettably, mostly undocumented and unknown.

13. According to Anderson, chart statistics were largely manipulated during this period. Reasons given varied from the withholding of royalties for artists to racial objectives (1981).

14. The forerunner of this movement was James Phillips, who was to go on to become a powerful critic of military service under the pseudonym of "Bertoldus Niemand."

15. The "authentic" versus "progressive" debate is, admittedly, a contentious one. Organizers of the revived boeremusiek competitions, promoters of the revised kwela pennywhistle style and even those interested in the phenomenon of the revived isicathamiya styles within 
a modern idiom (especially following the Graceland album) were confronted by the dilemma of whether the fusion of traditional and modern forms was a threat to the preservation of styles, or an assurance of their continued survival through their integration into the everyday. While the debate is important, elements of elitism have unfortunately crept into it, and musicians have expressed frustration with the criticism of purists who consider improvisatory works based around old forms as purely commercial, at the expense of the form. Further dissatisfaction lies in the contention that issues of identity (in music) are confused by erudite readings into them. Ironically, the critique that scholars have leveled at colonial anthropologists is remarkably applicable to present-day approaches toward the representations of "others," but for almost diametrically opposed reasons. While previous constructions of identity may have had complex political motivations, many similarly misguided constructions are formulated today in the interests of cultural relativity. Distorted images are presented not out of ignorance, but out of sophistry, and the danger of ill-informed imperialists creating identities for political ends is often being replaced by well-informed academics intellectualizing people out of their own existence.

16. The individual efforts of archivists and musicians like Hugh Tracy, his son Andrew, Rob Allingham, Albert Ralulini, and Dave Marks, as well as the institutional work of the International Library of African Music and Gallo Archives serve as important centers for the collection and referencing of musical forms previously considered mere remnants of a forgotton past. Private enterprises have been important in the wake of state irresponsibility, such as the destruction of the bulk of "African" recordings of the SABC, when the broadcasting corporation was preparing to move to their new premises in Johannesburg in the late 1970s.

17. Melodies by composers such as Weber, Mozart, Mendelssohn, Schubert, Berlioz, Brahms, and Gluck have all become integrated into the Afrikaans "volksliedje" repertoire (Federasie van Afrikaanse Kultuurvereniginge 1986).

18. There are, of course, the questions of who the audiences were, who were buying the recordings, and how the interactions between audiences and musicians affected both the production and reception of the music. While this is a salient and interesting issue, it is beyond the scope of this study. It deserves to be investigated, however, for it will reveal important aspects of the music indaba not dealt with in this article.

19. Of course I here refer to collaborations that became public, and acknowledge the importance of the even more numerous private collaborations that were instrumental in the development of the movement.

20. As was the case with much of the unrecorded underground music, many of the most well-loved musical experiments of the late-apartheid era were only recorded in the post-apartheid era. Local record labels have brought out a great many compilations of these contentious songs since the elections to save the "classics" of the movement.

21. Some of the more prominent musicians involved were Hugh Masekela, Yvonne Chaka Chaka, Brenda Fasie, Marc Alex, P. J. Powers, Little Sister and No Friends of Harry.

22. A prominent proponent of township kwela today is Clare Johnson (lead singer of Mango Groove), a white Englishwoman from Johannesburg, while one of the most respected composers of ethnoclassical music is the Zulu professor James Khumalo, from the Department of African Languages at the University of Witwatersrand.

23. At events in South Africa, America, and even Russia I have been saddened to observe that influential early protest artists like Johnny Clegg of South Africa and Boris Grebenshchikov of Russia are occasionally ridiculed nowadays for the "dated" sentiments they expressed in the late-Apartheid and late-Soviet eras.

\section{References}

Allen, Lara Victoria. 1993. "Pennywhistle Kwela: A Musical, Historical and Socio-Political Analysis." Master's thesis. University of Natal. 
Anderson, Benedict. 1983. Imagined Communities: Reflections on the Origin and Spread of Nationalism. London: Verso.

Anderson, Muff. 1981. Music in the Mix: The Story of South African Popular Music. Johannesburg: Ravan.

Anzaldua, Gloria. 1987. Borderlands-La Frontera; The New Mestiza. San Francisco: Spinsters/Aunt Lute Book Company.

Attali, Jacques. 1992. The Political Economy of Music. Minneapolis: University of Minnesota Press.

Bakhtin, Mikhail. 1935. "Discourse in the Novel." In The Dialogic Imagination: Four Essays. Reprinted 1981. Austin: University of Texas Press.

Ballantine, Christopher. 1989. "A Brief History of South African Popular Music." Popular Music 8(3):304-10.

- 1991a. "The Foundations of Black Jazz in South Africa between the Twenties and the Early Forties." Popular Music 10(2):121-46.

1991b. "Music and Emancipation: The Social Role of Black Jazz and Vaudeville in South Africa between the 1920s and the Early 1940s." Journal of Southern African Studies 17(1):129-52.

- 1993. Marabi Nights. Johannesburg: Ravan.

Brown, P. and Levinson, S. 1978. Politeness: Some Universals in Language Usage. Cambridge: Cambridge University Press.

Bourdieu, Pierre. 1977. Outline of a Theory of Practice. Cambridge: Cambridge University Press.

Byerly, Ingrid. 1996. "The Music Indaba: Music as Mirror, Mediator and Prophet in the South African Transition from Apartheid to Democracy." Ph.D. diss., Duke University.

Clegg, Johnny. 1981. "The music of Zulu immigrant workers in Johannesburg: A Focus on Concertina and Guitar." Paper presented at the First Symposium on Ethnomusicology, Rhodes University, Grahamstown.

— 1982. "Towards an Understanding of African Dance: The Zulu Isishameni Style." Paper presented at the Second Symposium on Ethnomusicology, Rhodes University, Grahamstown.

Comaroff J. and Comaroff, J. 1991. Of Revelation and Revolution: Christianity, Colonialism, and Consciousness in South Africa. Chicago: University of Chicago Press.

Coplan, David. 1978. "The African Musician and the Development of the Johannesburg Entertainment Industry." Journal of Southern African Studies 5(2):135-64.

- 1979-80. "Marabi Culture: Continuity and Transformation in African Music in Johannesburg, 1920-1940." African Urban Studies 6:49-75.

— 1982a. "The Emergence of an African Working Class Culture." In Industrialisation and Social Change in South Africa, edited by Shula Marks and Richard Rathbone. London: Longman.

— 1982b. "The Urbanisation of Popular African Music: Some Theoretical Observations." Popular Music 2:113-30.

- 1985. In Township Tonight! South Africa Black City Music and Theatre. London: Longman.

— 1988 "Musical Understanding: The Ethnoaesthetics of Migrant Workers' Poetic Song in Lesotho." Ethnomusicology 32(3):337-67.

- 1994. In the Time of Cannibals. Chicago: University of Chicago Press.

Cushman, Thomas. 1995. Notes from Underground: Rock Music Counterculture in Russia. SUNY Series in the Sociology of Culture, edited by Charles R. Simpson. New York: State University of New York Press.

Davies, Nollene. 1994. "The Guitar in Zulu maskanda Tradition." The World of Music 36(2):118-37.

Durkheim, Emile. 1984 (rep.) The Division of Labor in Society. New York: Free Press.

Eichbaum, Julius. 1993. "Politics and the Arts-The Mixture As Before?" Scenario, March:3-5. 
Erlmann, Veit. 1990. "Migration and Performance: Zulu Migrant Workers' Isicathamiya Performance in South Africa." Ethnomusicology 34(2):199-221.

—. 1991. African Stars. Studies in Black South African Performance. Chicago: University of Chicago Press.

Ewing, Katherine P. 1990. "The Illusion of Wholeness: Culture, Self and the Experience of Inconsistency." Etbos 18(3):251-78.

Federasie van Afrikaanse Kultuurvereniginge, 1986. FAK Sangbundel. Cape Town: Nasionale Boekdrukkery.

Fanon, Franz. 1961. The Wretched of the Earth. New York: Grove.

Feld, Steven, 1994. "Notes on World Beat" in Music Grooves by Charles Keil and Steven Feld, 238-246. Chicago: University of Chicago Press.

Fischer-Dieskau, Dietrich. 1976. Wagner and Nietzsche. New York: Seabury Press.

Friedl, Ernestine. 1964. "Lagging Emulation in Post-Peasant Society." American Antbropologist 66(3):569-86.

Hamm, Charles. 1985. "Rock 'n Roll in a Very Strange Society." In Popular Music 5: Continuity and Change, edited by Richard Middleton and David Horn. Cambridge: Cambridge University Press.

1988. Afro-American Music, South Africa and Apartheid. I.S.A.M. Monographs no. 28. Institute for Studies in American Music. Brooklyn: Brooklyn College of the City University of New York.

1989. “'Graceland' Revisited.” Popular Music 8(3):299-303.

. 1991. “'The Constant Companion of Man': Separate Development, Radio Bantu and Music.” Popular Music 10(2):147-74.

Hebdige, Dick. 1979. Subculture: The Meaning of Style. London: Methuen.

Henriques, E. L. 1984. Changing the Subject. Cambridge: Cambridge University Press

James, Deborah. 1991. "Musical Form and Social History." Radical History Review 46(7):4756.

. 1994. "Basadi ba Baeng/visiting women: Female Migrant Performance from the Northern Transvaal." In Politics and Performance: Theatre, Poetry and Song in Southern Africa, edited by Liz Gunner. Johannesburg: University of the Witwatersrand Press.

Keegan, Tim. 1988. Facing the Storm: Portraits of Black Lives in Rural South Africa. London: Zed.

Kivnick, Helen. 1990. Where Is the Way? Song and Struggle in South Africa. London: Penguin.

Kondo, Dorinne. 1990. Crafting Selves. Chicago: University of Chicago Press.

Levy, Michael. 1986. "African and Western Music: Shall the Twain Ever Meet?" South African Journal of Musicology vi:111-5.

- 1992. "Presentation of Three South African Cross-Cultural Orchestral Pieces." Paper presented at the General Assembly of the International Society for Contemporary Music "World Music Days," Warsaw, Poland.

Leont'ev, Mikhail. 1972. "The Problem of Activity in Psychology." Voprosy Filosofi 9:95-108.

Lévi-Strauss, Claude. 1962. The Savage Mind. Chicago: University of Chicago Press.

Meintjes, Louise, 1990. "Paul Simon's 'Graceland' in South Africa and the Mediation of Musical Meaning.” Ethnomusicology 34(1):37-73.

Muller, Carol. 1994. "Nazarite Song, Dance and Dreams: The Sacralization of Time, Space and the Female Body in South Africa." Ph.D. diss., New York University.

Roosenschoon, Hans. 1992. "Keeping our Ears to the Ground: Cross-Culturalism and the Composer in South Africa." Paper presented at the General Assembly of the International Society for Contemporary Music "World Music Days," Warsaw, Poland.

Rorich, Mary. 1989. "Shebeens, Slumyards and Sophiatown: Black Women, Music and Cultural Change in Urban South Africa." World of Music 31(1):78-101.

Smit, Brendon. 1992. "Afrikaans Alternative Popular Music 1986-1990: An Analysis of the Music of Bernoldus Niemand and Johannes Kerkorrel.” B.Mus. thesis, University of Natal. 
Taylor, Timothy. 1995. "When We Think about Music and Politics: The Case of Kevin Volans." Perspectives of New Music 33(1\&2):506-36.

Thompson, Hunter S. 1971. Fear and Loathing in Las Vegas: A Savage Journey to the Heart of the American Dream. New York: Random House.

Tomaselli, Kenyan and Boster, Bob. 1993. "Mandela, MTV, Television and Apartheid." Popular Music and Society 17(2):1-21.

Tonnies, Ferdinand. 1957. Gemeinschaft und Gesellschaft. New York: Harper and Row.

Vail, Leroy and White, Landeg. 1991. Power and the Praise Poem: Southern African Voices in History. Charlottesville: University of Virginia Press.

Valsiner, Jaan. 1991. "Building a Theoretical Bridge over a Lagoon of Everyday Events." $\mathrm{Hu}$ man Development 34:307-15.

— 1992. "Bi-Directional Cultural Transmission and Constructive Sociogenesis." In Mechanisms of Sociogenesis, edited by Willibrord de Graaf and Robert Maier. New York: Springer.

Van Schalkwyk, Anastasia. 1994. "The Voice of Protest: Urban Black Women, Song and Resistance in the 1980's." Master's thesis, University of Natal.

Wells, Robin E. 1994. An Introduction to the Music of the Basotho. Lesotho: Morija Museum and Archives.

Wertsch, J. V. 1991. Voices of the Mind: A Sociocultural Approach to Mediated Action. Boston: Harvard University Press.

White, Landeg. 1982. "Power and the Praise Poem." Journal of Southern African Studies $9(1): 8-32$.

Wolf, Eric. 1982. Europe and the People without History. Berkeley: University of California Press. 